Article

\title{
Reliability and Efficiency of Pollutant Removal in Four-Stage Constructed Wetland of SSVF-SSHF-SSHF-SSVF Type
}

\author{
Magdalena Gizińska-Górna, Krzysztof Jóźwiakowski and Michał Marzec *i \\ Department of Environmental Engineering and Geodesy, University of Life Sciences in Lublin, Akademicka 13, \\ 20-950 Lublin, Poland; magdalena.gizinska-gorna@up.lublin.pl (M.G.-G.); \\ krzysztof.jozwiakowski@up.lublin.pl (K.J.) \\ * Correspondence: michal.marzec@up.lublin.pl
}

Received: 14 October 2020; Accepted: 6 November 2020; Published: 11 November 2020

check for updates

\begin{abstract}
The present paper reports pollutant removal efficiencies and reliability for a four-stage hybrid constructed wetland (HCW) consisting of the following sequence of subsurface (SS), vertical flow (VF) and horizontal flow (HF) beds: SSVF-SSHF-SSHF-SSVF. The experiments were carried out over a period of three years, with sampling done in each season: winter, spring, summer and autumn. Grab samples of wastewater collected from different stages of treatment were tested for total suspended solids (TSS), $\mathrm{BOD}_{5}, \mathrm{COD}$, total nitrogen (TN) and total phosphorus (TP). The wetland was found to have a very high efficiency of removal of suspended solids and organics, with relatively little seasonal variability. The three-year average TSS removal efficiency was approximately $92.7 \%$. The effectiveness of elimination of organic compounds was very high throughout the study period at $96.6 \% \mathrm{BOD}_{5}$ and $95 \% \mathrm{COD}$. The effluent from the four-stage system had significantly lower contents of TN and TP compared to the wastewater discharged from the first two beds of this facility.
\end{abstract}

Keywords: wastewater treatment; hybrid constructed wetland; removal efficiency; reliability

\section{Introduction}

Local sewage treatment plants are an ideal solution for the disposal of small amounts of wastewater in areas with a dispersed development pattern, where the construction of a collective sewage system is economically unviable. Today, the market offers a number of different technological designs for the treatment of small quantities of wastewater. However, more and more often, the selection of a treatment technology is guided by the ecological criterion [1-3]. This is why constructed wetlands (CWs), which provide highly efficient removal of pollutants, are gaining in popularity, especially in rural settings, protected areas and areas of a high landscape value [4-7]. CWs are most commonly classified on the basis of the wastewater flow regime. According to this division, there are two main types of such facilities: free-water surface flow (FWS) and subsurface flow (SS) CWs. The latter are further divided into horizontal flow (SSHF) and vertical flow (SSVF) wetlands. In SSVF systems, wastewater is dosed onto the surface of the bed and then drains by gravity to the bottom layer [8]. A bed of this type consists of several layers of filling material (gravel and sand), with the layers having a progressively smaller grain size from bottom to top. In the Polish climate, SSVF CWs perform much better than FWS CWs.

The CWs used in Poland are usually two-stage systems with a SSVF bed and a SSHF bed. Three- and four-stage CWs are less frequently used. The only examples of such systems described in the Polish literature are the facilities in Darżlubie (SSHF-SSHF-SSVF-SSHF), Wiklino (SSHF-SSVF-SSHF), Wieszyn (SSHF-SSVF-SSHF) and Schodno (SSHF-SSHF-SSVF-SSVF), investigated by Gajewska 
and Obarska-Pempkowiak [9]. This study reports, for the first time, the results of an analysis of a SSVF-SSHF-SSHF-SSVF wetland.

Numerous studies have shown the effectiveness of soil-plant systems in the removal of various types of pollutants, such as organic matter, pathogens and pharmaceuticals $[10,11]$. They are slightly less efficient in removing biogenic elements, such as total nitrogen (TN) and total phosphorus (TP). In these systems, nitrogen and phosphorus are eliminated from wastewater with various efficiencies, which is associated with the specific nature of nitrification and denitrification and the processes that lead to the reduction of phosphorus compounds [12,13]. For that reason, new solutions that would optimize the conditions of nutrient removal are being looked for. One such option is the use of CW systems $[11,14,15]$. In these systems, vertical flow (SSVF) beds create better conditions for nitrification owing to pulsed wastewater dosing. Much better oxygenation of the sewage flowing into SSVF beds also creates favorable conditions for very effective elimination of organic matter, expressed as $\mathrm{BOD}_{5}$ and COD. On the other hand, horizontal flow (SSHF) beds ensure a high efficiency of elimination of organic matter and total suspended solids (TSS) and can create very good conditions for denitrification. Purified wastewater at the outflow from CWs has lower concentrations of organic matter. CWs also ensure full nitrification and partial denitrification of wastewater, and hence, discharge lower concentrations of TN in their effluent $[6,7,16]$.

One line of research on CWs focuses on the introduction of new plant species that could improve the efficiency of removal of contaminants and ensure a longer life of these soil-plant systems [17]. To date, CWs in Europe and worldwide have usually been planted with Phragmites spp. (Poaceae), Typha spp. (Typhaceae), Scirpus spp. (Cyperaceae), Iris spp. (Iridaceae), Juncus spp. (Juncaceae), Eleocharis spp. (Cyperaceae) and Salix $[4,6,18]$. To a lesser extent, systems of this type use energy crops, such as the giant miscanthus (Miscanthus $\times$ giganteus Greef et Deu) or the Jerusalem artichoke (Helianthus tuberosus L.). Currently, there is scant literature on the pollutant removal efficiency of CWs planted with these species. Giant miscanthus and Jerusalem artichoke can be harvested for energy production. In the case of constructed farm wetlands, biomass obtained from those plants can be used as a cheap source of energy by farmers, especially those who specialize in the production of flowers and vegetables in greenhouses, which are now normally heated using sawdust stoves. In this light, the type of wetland discussed in this study can not only be used to effectively reduce pollutant loads in wastewater, but it can also be harnessed to provide a source of alternative energy [19].

The goal of the present study was to determine the effectiveness and reliability of removal of organic contaminants (TSS, $\mathrm{BOD}_{5}$, and COD), biogenic elements (TN and TP) in a SSVF-SSHF-SSHF-SSVF $\mathrm{CW}$ and to assess the role of energy crops in wastewater treatment processes. The effectiveness of removing pollutants from wastewater and their quality at individual stages of treatment were analyzed, and then the validity/desirability of using multi-stage constructed wetlands systems was assessed.

\section{Material and Methods}

\subsection{Characteristics of the Experimental Facility}

The investigated wastewater treatment plant was located in Dabrowica (a village in the Lublin Province, Poland) $\left(51^{\circ} 16^{\prime} 13.80^{\prime \prime} \mathrm{N} 22^{\circ} 27^{\prime} 14.72^{\prime \prime}\right.$ E). In this facility, domestic wastewater influent was first routed through a concrete primary settling tank consisting of three chambers covered with cast iron manhole covers. The chambers were arranged in a series. Because the settling tank had been converted from a pre-existing septic tank, wastewater flowed from one chamber to the next by gravity. The first chamber had a volume of $4.41 \mathrm{~m}^{3}(\phi 1.5 \mathrm{~m}$ and $\mathrm{h} 2.5 \mathrm{~m})$, and the second and third chambers had a volume of $1.76 \mathrm{~m}^{3}(\phi 1.5 \mathrm{~m}$ and $\mathrm{h} 2.0 \mathrm{~m})$ each. The working volumes were $2.65 \mathrm{~m}^{3}$ for the first chamber and $0.88 \mathrm{~m}^{3}$ for the second and third chambers each.

After preliminary mechanical treatment in the primary settling tank, which involved sedimentation of solid waste, wastewater flowed through a series of four SS beds connected in the following order: SSVF-SSHF-SSHF-SSVF. The sequential beds were planted with common reed (Phragmites australis 
Cav. Trin. ex Steud.), Salix (Salix viminalis L.), Jerusalem artichoke (Helianthus tuberosus L.) and giant miscanthus (Miscanthus $\times$ giganteus Greef et Deu.). Each bed was $4 \mathrm{~m}$ long $\times 6 \mathrm{~m}$ wide, which means the CW had a total surface area of $96 \mathrm{~m}^{2}$. The SSVF beds (I and IV) were $0.8 \mathrm{~m}$ deep, and the SSHF beds (II and III) were $1.2 \mathrm{~m}$ deep. The SSVF beds were filled with a layer of sand (1-2 mm grain size) to a height of about $0.8 \mathrm{~m}$. In SSHF beds, a $1 \mathrm{~m}$ bottom layer of sand (1-2 $\mathrm{mm}$ grain size) was topped with a $0.2 \mathrm{~m}$ layer of humus soil excavated during the construction of the wetland. All beds were lined with $1 \mathrm{~mm}$ thick geomembrane. In the SSVF beds, wastewater was dosed periodically with a pump. The operation frequency of the pump depended on the amount of influent sewage. Wastewater was pumped onto the surface of the SSVF beds and then flowed vertically down to the drainage layer at the bottom of the bed and into a distribution box. Both SSVF beds experienced wet and dry periods depending on the amount of inflowing sewage. In the case of the SSHF bed with Salix, wastewater was fed into the bed by gravity. It entered one side of the bed and flowed across it under the surface. A tilting pipe installed at the outflow from the SSHF beds was used to raise the wastewater level in both SSHF beds in the summer. In cold periods (below $-8^{\circ} \mathrm{C}$ ), the wastewater level was maintained at $0.4 \mathrm{~m}$ above the bottom of the beds, and in the summer it was raised to $0.8 \mathrm{~m}$.

During the study period, the facility serviced a family of eight (Figure 1). The mean hydraulic load was $0.6 \mathrm{~m}^{3} \cdot \mathrm{d}^{-1}$. Every year, after the winter season, the aboveground plant shoots and part of the tubers (Jerusalem artichoke) were removed from the fields. The volume of sewage flowing into the treatment plant was determined on the basis of readings of water meters installed in the building and average water consumption.

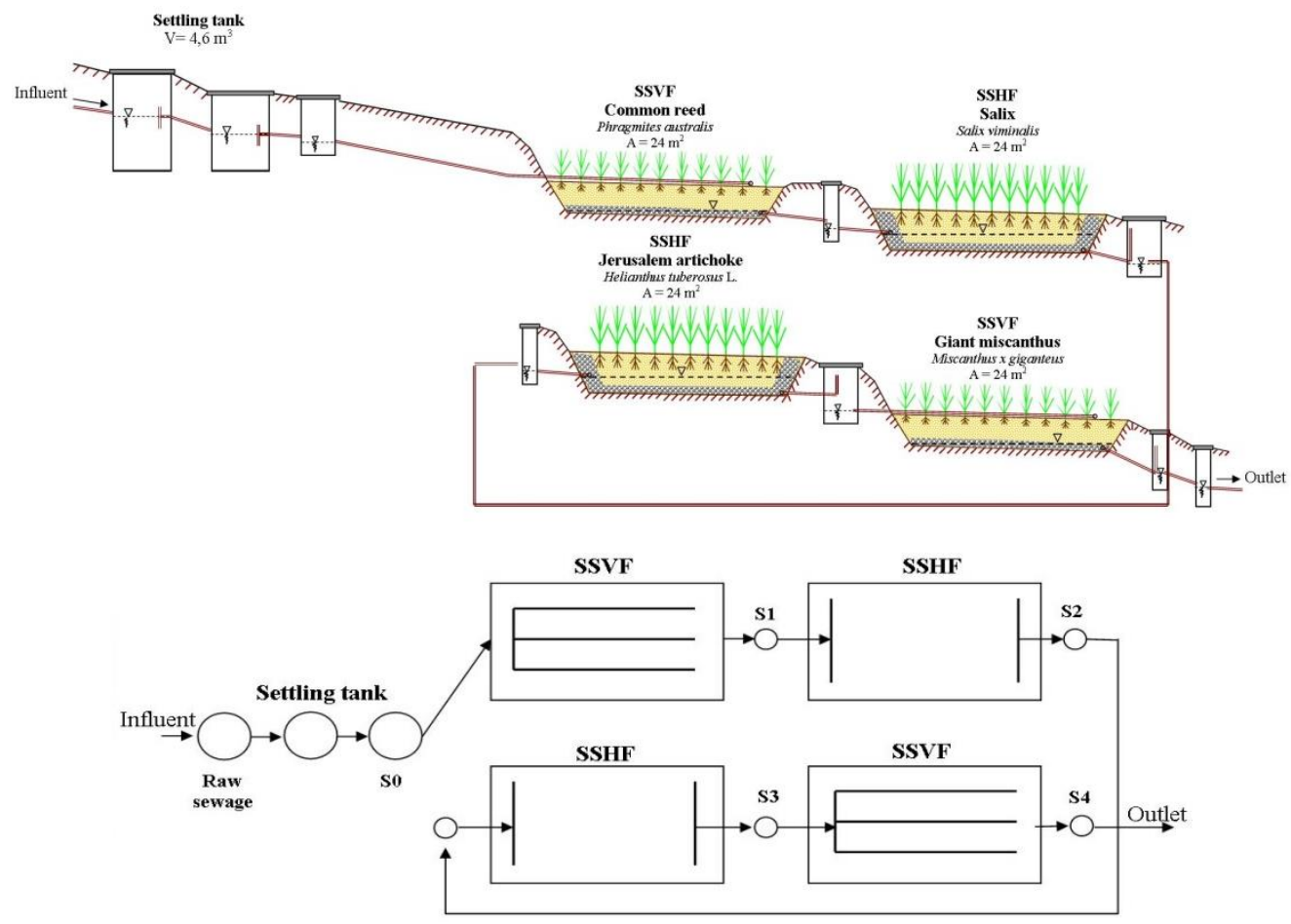

Figure 1. Technological scheme of the SSVF-SSHF-SSHF-SSVF hybrid constructed wetland with sampling points S0, S1, S2, S3 and S4. (SSVF—subsurface vertical flow, SSHF-subsurface horizontal flow).

The theoretical hydraulic retention time (HRT) was determined on the basis of the parameters of the beds (horizontal dimensions, porosity of the material used to fill the beds, the height of the layer filled with sewage) and average daily wastewater inflow [20]. The HRT for VF beds was $2.4 \mathrm{~d}$. Thanks to the use of the tilting pipe downstream of both SSHF beds, the HRT in both beds was extended to about $12.8 \mathrm{~d}$, and in cold periods to $6.4 \mathrm{~d}$. 


\subsection{Experimental Procedure}

Pollutant removal efficiency was assessed by determining TSS, $\mathrm{BOD}_{5}, \mathrm{COD}, \mathrm{TN}$, ammonium nitrogen (NH4-N), nitrite nitrogen, nitrate nitrogen and TP content in samples collected from the analyzed facility in three consecutive years (2011-2013). Sewage samples were collected each year in February, May, August, September and November. Sampling dates were chosen to reflect season changes in a warm climate in which the average annual air temperature is about $8.8^{\circ} \mathrm{C}$ [21].

Wastewater samples for physical and chemical assays were labelled as follows: $\mathrm{S} 0$-mechanically treated raw sewage collected downstream of the settling tank, S1-effluent from the SSVF bed with common reed, S2-effluent from the SSHF bed with Salix, S3 - effluent from the SSHF bed with Jerusalem artichoke and S4-effluent from the SSVF with giant miscanthus (Figure 1).

\subsection{Analytical Methods}

The analyses were carried out in accordance with the sample analysis procedures described in the Regulation of the Polish Minister of the Environment of 2014 [22]. Samples were collected, transported, processed and analyzed in accordance with Polish standards [23-29], which comply with APHA [30].

The following methods were used:

- $\quad$ TSS - gravimetry directly after filtration through filters and drying at $105^{\circ} \mathrm{C}$.

- $\quad \mathrm{BOD}_{5}$ - dilution test. Oxygen was measured before and $5 \mathrm{~d}$ after incubation at $20{ }^{\circ} \mathrm{C}$ in total darkness with the addition of a nitrification inhibitor.

- COD—dichromate test. $\mathrm{COD}_{\mathrm{Cr}}$ was determined after oxidation of a sample in a thermoreactor at $148^{\circ} \mathrm{C}$.

- $\quad \mathrm{TN}$ - photometric method after oxidation of a sample in a thermoreactor at $100^{\circ} \mathrm{C}$.

- Nitrate nitrogen and nitrite nitrogen - photometric method.

- Ammonium nitrogen - photometric method using a spectrophotometer.

- $\quad \mathrm{TP}$ - photometric method after oxidation of a sample in a thermoreactor at $120^{\circ} \mathrm{C}$.

Based on the test results, the minimum, maximum and mean values of the investigated parameters as well as standard deviations were determined (Table 1 ). The mean concentrations of the analyzed pollution indicators in influent $\left(C_{i n}\right)$ and effluent $\left(C_{\text {out }}\right)$ wastewater were used to calculate the mean pollutant removal efficiencies of the beds according to Formula (1):

$$
\mathrm{D}=100 \times\left(1-\mathrm{C}_{\text {out }} / \mathrm{C}_{\text {in }}\right)(\%)
$$

The assessment of the efficiency of the treatment plant was complemented by calculating the mass removal rates (MRRs) for the main pollutants contained in the wastewater. MRRs were determined using the formula below [31]:

$$
M R R=\frac{C_{i n} Q_{i n}-C_{\text {out }} Q_{\text {out }}}{A}\left(\mathrm{~g} / \mathrm{m}^{2} / \text { day }\right)
$$

where $A$-surface area of a $\mathrm{CW}\left(\mathrm{m}^{2}\right), Q_{i n}$ and $Q_{o u t}$-mean quantities of influent and effluent wastewater $\left(\mathrm{m}^{3} /\right.$ day), $C_{\text {in }}$ and $C_{\text {out }}$ - mean concentrations of a contaminant at the inflow to and outflow from the $\mathrm{CW}\left(\mathrm{g} / \mathrm{m}^{3}\right)$.

Table 1. Ratios between mean values of selected pollution indicators.

\begin{tabular}{ccc}
\hline Relationship & Literature Recommendation [32] & This Study \\
\hline $\mathrm{COD} \mathrm{BOD}_{5}$ & $\leq 2.2$ & 2.43 \\
$\mathrm{BOD}_{5} / \mathrm{TN}$ & $\geq 4.0$ & 1.30 \\
$\mathrm{BOD}_{5} / \mathrm{TP}$ & $\geq 25$ & 8.78 \\
\hline
\end{tabular}


The calculated values were theoretical because they were based on the assumption that the volume of wastewater flowing out from the individual beds was equal to the volume of influent wastewater.

\subsection{Statistical Analysis}

In addition, the correlations between air temperature and removal efficiencies for TN and TP were determined. The null hypothesis that there was no relationship between the analyzed variables

$$
\mathrm{H}_{0}: \rho=0
$$

was tested against the alternative hypothesis

$$
\mathrm{H}_{0}: \rho \neq 0
$$

where $\mathrm{H}_{0}$-null hypothesis, and $\rho$-linear correlation coefficient stating that there was a relationship between the investigated variables.

Correlations were determined using Pearson's test, and statistical significance was confirmed by Student's $t$-test at the significance level $\alpha=0.05$. Absolute values of the $t$-tests were compared against the critical values given in Student's t-distribution tables. The correlation coefficient was considered statistically significant if $|\mathrm{t}| \geq \mathrm{t} \alpha_{\mathrm{kr}}$.

Sampling frequency was selected in compliance with the provisions of Polish law [22], which recommends that in the case of small wastewater treatment plants (representing PE less than 2000) four wastewater samples should be taken per year under a routine pre-scheduled sampling program. Because of the possibility of occurrence of extreme events, the reliability of discharge compliance monitoring tests may be questioned, but the results obtained in these tests are sufficient to evaluate the performance of a treatment plant. In the case of the facility investigated in the present study, wastewater samples were collected and tested outside periods of intense rainfall and spring thaws, which could significantly affect the results.

Reliability was assessed for the basic pollution parameters $\left(\mathrm{BOD}_{5}, \mathrm{COD}\right.$, total suspended solids, total nitrogen and total phosphorus) using elements of Weibull's theory of reliability. The Weibull distribution is a useful general probability distribution applicable in reliability testing and assessment of risk of exceedance of discharge limits [4,33-36]. The Weibull distribution is characterized by the following probability density function:

$$
f(x)=\frac{c}{b} \cdot \frac{x-\theta}{b}^{(c-1)} \cdot e^{-\frac{x-\theta^{c}}{b}}
$$

where $x$-variable defining the discharge concentration of a pollutant, $b$-scale parameter, $c$-shape parameter and $\theta$-location parameter, under the assumption that $\theta<x, b>0, c\rangle 0$.

Reliability analysis was carried out separately for each parameter using the discharge values. The analysis consisted in estimating the Weibull distribution parameters by the maximum likelihood method and verifying the null hypothesis that the variable tested could be described by the Weibull distribution.

Reliability was determined from the cumulative distribution function using the discharge limits for the investigated parameters set in the Regulation of the Polish Minister of the Environment [22] for wastewater discharged from treatment plants with PE less than 2000: $\mathrm{BOD}_{5}-40 \mathrm{mgO}_{2} / \mathrm{L}, \mathrm{COD}-150 \mathrm{mgO} / \mathrm{L}$, total suspended solids $-50 \mathrm{mg} / \mathrm{L}$, total nitrogen $-30 \mathrm{mg} / \mathrm{L}$ and total phosphorus $-5 \mathrm{mg} / \mathrm{L}$. In the case of nitrogen and phosphorus, we adopted limits specified for wastewater discharged into lakes and their tributaries, and directly to artificial reservoirs located on flowing waters [22]. 


\section{Results and Discussion}

\subsection{Composition of Wastewater Treatment}

\subsubsection{Composition and Quality of Raw Sewage}

The mean pollution indicator values for raw sewage flowing from the house to the primary settling tank were $321.5 \mathrm{mg} / \mathrm{L}$ for $\mathrm{BOD}_{5}, 708.2 \mathrm{mg} / \mathrm{L}$ for COD, $397.6 \mathrm{mg} / \mathrm{L}$ for TSS, $150 \mathrm{mg} / \mathrm{L}$ for TN and $23.1 \mathrm{mg} / \mathrm{L}$ for TP (Table 2). These values were similar to those typically reported for domestic sewage in Poland $[32,37,38]$.

Table 2. Contaminant concentrations at the individual stages of treatment in the SSVF-SSHFSSHF-SSVF system.

\begin{tabular}{|c|c|c|c|c|c|c|c|}
\hline \multirow{2}{*}{ Parameters } & \multirow{2}{*}{ Sample } & \multicolumn{6}{|c|}{ Statistic } \\
\hline & & Average & Median & Min & $\operatorname{Max}$ & SD & $\mathrm{Cv}$ \\
\hline \multirow{6}{*}{$\begin{array}{l}\text { Dissolved oxygen } \\
\qquad\left(\mathrm{mgO}_{2} / \mathrm{L}\right)\end{array}$} & RW & 0.22 & 0.17 & 0.10 & 0.34 & 0.08 & 0.35 \\
\hline & So & 0.93 & 0.32 & 0.10 & 2.51 & 0.97 & 1.04 \\
\hline & S1 & 4.69 & 4.65 & 2.60 & 6.36 & 1.12 & 0.24 \\
\hline & S2 & 3.24 & 7.06 & 4.25 & 9.21 & 1.79 & 0.25 \\
\hline & S3 & 3.23 & 6.12 & 4.15 & 11.02 & 1.91 & 0.31 \\
\hline & S4 & 7.32 & 7.83 & 2.98 & 11.31 & 2.19 & 0.30 \\
\hline \multirow{6}{*}{$\mathrm{pH}$} & RW & 7.07 & 7.15 & 6.13 & 7.64 & 0.37 & 0.05 \\
\hline & S0 & 7.23 & 7.32 & 6.42 & 7.60 & 0.32 & 0.04 \\
\hline & S1 & 7.16 & 7.17 & 6.35 & 7.65 & 0.35 & 0.05 \\
\hline & $\mathrm{S} 2$ & 7.36 & 7.49 & 6.56 & 7.82 & 0.40 & 0.05 \\
\hline & S3 & 7.41 & 7.40 & 6.66 & 7.98 & 0.35 & 0.05 \\
\hline & $\mathrm{S} 4$ & 7.67 & 7.87 & 6.93 & 8.06 & 0.44 & 0.06 \\
\hline \multirow{6}{*}{$\mathrm{BOD}_{5}\left(\mathrm{mgO}_{2} / \mathrm{L}\right)$} & RW & 321.45 & 189.00 & 189.00 & 679.00 & 136.47 & 0.42 \\
\hline & So & 146.6 & 129.0 & 68.0 & 232.0 & 50.9 & 0.3 \\
\hline & S1 & 5.1 & 4.4 & 1.0 & 10.4 & 3.3 & 0.6 \\
\hline & $\mathrm{S} 2$ & 4.7 & 4.1 & 1.0 & 10.4 & 3.2 & 0.7 \\
\hline & S3 & 4.6 & 4.8 & 0.7 & 9.2 & 2.6 & 0.6 \\
\hline & S4 & 4.6 & 3.9 & 0.5 & 12.8 & 4.1 & 0.9 \\
\hline \multirow{6}{*}{$\begin{array}{c}\mathrm{COD} \\
\left(\mathrm{mgO}_{2} / \mathrm{L}\right)\end{array}$} & RW & 708.18 & 620.00 & 360.00 & 1300.00 & 332.23 & 0.47 \\
\hline & So & 356.4 & 330.0 & 230.0 & 490.0 & 91.7 & 0.3 \\
\hline & S1 & 32.7 & 23.0 & 11.0 & 76.0 & 21.8 & 0.7 \\
\hline & $\mathrm{S} 2$ & 18.5 & 13.0 & 7.0 & 38.0 & 11.8 & 0.6 \\
\hline & S3 & 21.4 & 20.0 & 5.0 & 36.0 & 9.4 & 0.4 \\
\hline & S4 & 17.2 & 18.5 & 7.0 & 26.0 & 6.6 & 0.4 \\
\hline \multirow{6}{*}{$\begin{array}{c}\text { TSS } \\
(\mathrm{mg} / \mathrm{L})\end{array}$} & RW & 397.61 & 176.00 & 164.00 & 812.70 & 209.04 & 0.53 \\
\hline & So & 106.2 & 109.0 & 61.0 & 151.4 & 30.6 & 0.3 \\
\hline & S1 & 34.2 & 16.3 & 2.0 & 120.3 & 50.0 & 1.2 \\
\hline & S2 & 14.5 & 14.5 & 4.3 & 36.9 & 8.9 & 0.6 \\
\hline & S3 & 7.4 & 8.3 & 2.2 & 14.7 & 4.4 & 0.6 \\
\hline & S4 & 5.4 & 4.1 & 1.0 & 15.5 & 4.7 & 0.9 \\
\hline \multirow{6}{*}{$\begin{array}{c}\mathrm{TN} \\
(\mathrm{mg} / \mathrm{L})\end{array}$} & RW & 149.91 & 160.00 & 94.00 & 256.00 & 50.63 & 0.34 \\
\hline & So & 112.8 & 118.0 & 70.0 & 148.0 & 22.6 & 0.2 \\
\hline & $\mathrm{S} 1$ & 82.1 & 75.0 & 51.0 & 123.0 & 21.3 & 0.3 \\
\hline & $\mathrm{S} 2$ & 78.6 & 72.0 & 52.0 & 119.0 & 19.1 & 0.2 \\
\hline & S3 & 70.0 & 71.0 & 55.0 & 94.0 & 11.1 & 0.2 \\
\hline & $\mathrm{S} 4$ & 60.0 & 60.0 & 39.0 & 83.0 & 13.2 & 0.2 \\
\hline
\end{tabular}


Table 2. Cont.

\begin{tabular}{cccccccc}
\hline \multirow{2}{*}{ Parameters } & Sample & \multicolumn{7}{c}{ Statistic } \\
\cline { 3 - 8 } & & Average & Median & Min & Max & SD & Cv \\
\hline \multirow{3}{*}{ Ammonium } & RW & 111.45 & 150.00 & 68.00 & 160.00 & 33.95 & 0.30 \\
nitrogen & S0 & 95.09 & 94.00 & 65.00 & 141.00 & 20.92 & 0.22 \\
(mg/L) & S1 & 9.84 & 1.07 & 0.08 & 49.70 & 16.97 & 1.73 \\
& S2 & 1.69 & 0.52 & 0.06 & 5.60 & 2.32 & 1.38 \\
& S3 & 0.53 & 0.52 & 0.05 & 1.30 & 0.43 & 0.82 \\
& S4 & 0.32 & 0.14 & 0.07 & 0.95 & 0.32 & 1.01 \\
\hline Nitrate nitrogen & RW & 1.22 & 1.14 & 0.16 & 3.16 & 1.17 & 0.96 \\
(mg/L) & S0 & 1.36 & 1.49 & 0.21 & 2.80 & 0.96 & 0.70 \\
& S1 & 38.12 & 36.02 & 23.53 & 57.24 & 11.65 & 0.31 \\
& S2 & 46.19 & 38.96 & 31.64 & 89.02 & 16.49 & 0.36 \\
& S3 & 37.14 & 40.14 & 14.86 & 49.40 & 10.41 & 0.28 \\
& S4 & 33.54 & 33.60 & 19.20 & 44.75 & 7.14 & 0.21 \\
\hline Nitrite nitrogen & RW & 0.27 & 0.16 & 0.16 & 0.48 & 0.12 & 0.45 \\
(mg/L) & S0 & 0.19 & 0.16 & 0.11 & 0.37 & 0.08 & 0.40 \\
& S1 & 0.27 & 0.17 & 0.03 & 0.75 & 0.25 & 0.93 \\
& S2 & 0.16 & 0.10 & 0.02 & 0.61 & 0.18 & 1.08 \\
& S3 & 0.40 & 0.26 & 0.04 & 1.21 & 0.38 & 0.95 \\
& S4 & 0.12 & 0.07 & 0.03 & 0.42 & 0.11 & 0.98 \\
\hline TP & RW & 23.10 & 7.10 & 7.10 & 41.90 & 11.38 & 0.49 \\
(mg/L) & S0 & 16.7 & 13.4 & 6.7 & 33.5 & 9.6 & 0.6 \\
& S1 & 8.6 & 8.4 & 6.3 & 13.3 & 2.0 & 0.2 \\
& S2 & 7.4 & 7.3 & 4.2 & 7.3 & 1.8 & 0.2 \\
& S3 & 6.4 & 6.3 & 4.7 & 6.3 & 1.0 & 0.2 \\
& S4 & 4.9 & 4.2 & 2.7 & 4.2 & 1.7 & 0.3 \\
\hline
\end{tabular}

Notation: RW—raw wastewater; S0—outflow from settling tank; S1—outflow from SSVF bed with common reed; S2-outflow from SSHF bed with Salix; S3 - outflow from SSHF bed with Jerusalem artichoke; S4-outflow from SSVF bed with giant miscanthus; SD—-standard deviation; $\mathrm{Cv}$-coefficient of variation.

\subsubsection{Efficiency of Removing Impurities in the Primary Settling Tank}

The primary settling tank was used to remove solid impurities. As a result of physical processes taking place in the sedimentation tank, mainly sedimentation of pollutants heavier than water, the TSS content decreased by almost $73 \%$. The division of the settling tank into two chambers had a positive effect on the degree of suspension elimination. It reduces the turbulence of the sewage, stabilizes the flow conditions, especially in the second chamber, and consequently prevents the sludge from being discharged. In the sewage flowing into the analyzed facility, as typical domestic sewage, the fraction of easily settling suspensions consists, to a large extent, of organic suspensions; hence, their removal from the sewage resulted in a significant reduction in BOD5 (by 54\%) and COD (by 50\%). The scale of this phenomenon depends on the presence of bacteria capable of anaerobic decomposition of organic matter. The settling tank is intended mainly for mechanical wastewater treatment; therefore, the effects of removing biogenic compounds were low, in the case of TN it was $25 \%$, TP-28\%.

Despite the relatively high efficiency of the settling tank, the value of $\mathrm{BOD}_{5}$ in the mechanically treated wastewater was on average $146 \mathrm{mg} / \mathrm{L}$. The concentrations of this indicator ranged between 100 and $150 \mathrm{mg} / \mathrm{L}$ in $45 \%$ of cases and were higher than $200 \mathrm{mg} / \mathrm{L}$ in $20 \%$ of cases. TSS concentrations did not exceed $450 \mathrm{mg} / \mathrm{L}$. Most TSS concentration values were in the range of $50-100 \mathrm{mg} / \mathrm{L}(45.5 \%)$ and $100-150 \mathrm{mg} / \mathrm{L}(36.5 \%)$, with a mean TSS concentration of $106.2 \mathrm{mg} / \mathrm{L}$. The mean level of COD in the wastewater mechanically treated in the primary settling tank was $356.4 \mathrm{mg} / \mathrm{L}$. The most frequently recorded COD values were in the range between 300 and $350 \mathrm{mg} / \mathrm{L}(27.5 \%$ of cases) and above $450 \mathrm{mg} / \mathrm{L}$ ( $27 \%$ of cases) (Figure 2). The remaining values (18\% of cases each) fell within the ranges of $200-250$ and $250-300 \mathrm{mg} / \mathrm{L}$. The differences among COD values measured in the mechanically treated wastewater leaving the settling tank could have been due to the variable composition of the 
raw sewage entering the tank as well as the operation and performance of the tank itself. TN and TP concentrations most often (36\% of cases) fell within the ranges of $120-140 \mathrm{mg} / \mathrm{L}$ and $10-15 \mathrm{mg} / \mathrm{L}$, respectively. The mean concentrations were $112.8 \mathrm{mg} / \mathrm{L}$ for TN and $16.7 \mathrm{mg} / \mathrm{L}$ for TP (Table 2). The values obtained in the present study were similar to those typically measured in wastewater treated in settling tanks [38-42].
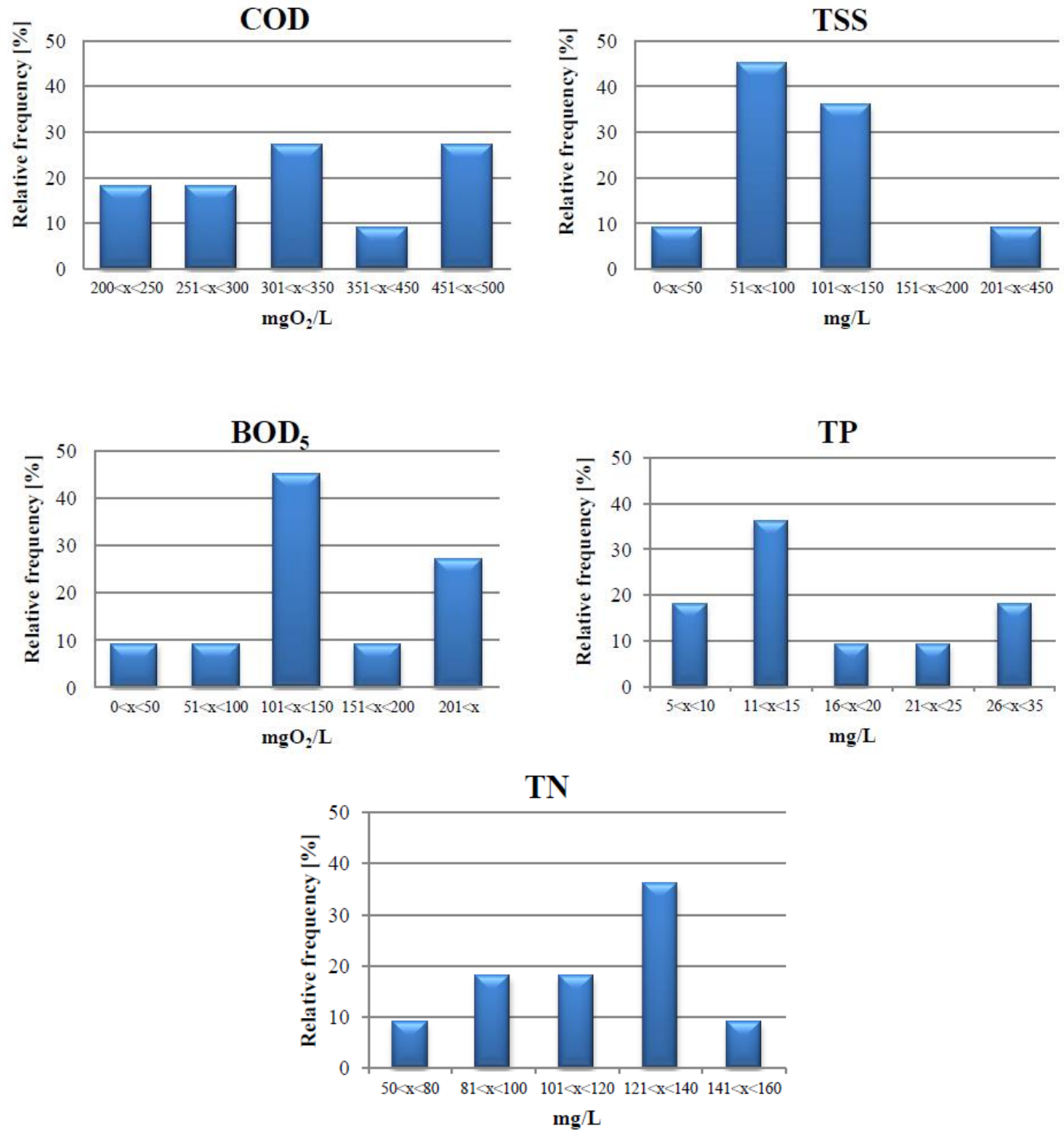

Figure 2. Frequency histograms for pollution parameters ( $\mathrm{BOD}_{5}, \mathrm{COD}, \mathrm{TSS}, \mathrm{TN}$ and TP) in the influent to the constructed wetland.

Effective removal of pollutants from wastewater in conventional biochemical processes requires the provision of appropriate quantities of nutrients for the optimal growth of the microorganisms participating in the treatment. Especially important is the availability of organic matter, nitrogen and phosphorus. The optimum concentrations of these nutrients in wastewater treated in a settling tank are expressed by ratios between pairs of the following pollution parameters: $\mathrm{BOD}_{5}, \mathrm{COD}, \mathrm{TN}$ and TP [32] (Table 1). 
As shown in Table 1, all the ratios calculated in this study deviated from the recommended ratios. These data indicate that the wastewater flowing into the investigated CW from the settling tank showed low susceptibility to biochemical degradation [32].

\subsubsection{Efficiency of Wastewater Treatment in the VF Bed with Common Reed}

After treatment in the SSVF reed bed, the concentration of $\mathrm{BOD}_{5}$ in wastewater dropped to $10.45 \mathrm{mg} / \mathrm{L}$. The mean concentration of TSS at the outflow from this bed was $34.2 \mathrm{mg} / \mathrm{L}$, and the concentration of COD was $32 \mathrm{mg} / \mathrm{L}$ (Table 2). The concentrations of the biogenic compounds TN and TP were $82.1 \mathrm{mg} / \mathrm{L}$ and $8.6 \mathrm{mg} / \mathrm{L}$, respectively (Table 2). Gikas and Tsihrintzis [43], who analyzed a system of two parallel SSVF reed beds, recorded maximum effluent concentrations of nitrogen in the range from 82.9 to $106.7 \mathrm{mg} / \mathrm{L}$. These values were similar to those obtained in the present study. The concentrations of organic pollutants, expressed as $\mathrm{BOD}_{5}$ and $\mathrm{COD}$, in wastewater treated in the SSVF bed with common reed were clearly lower than the admissible values stipulated by the Polish law (Figure 3) [22]. In the case of TSS, the quality of wastewater leaving the single-stage system fell short of the requirements set out in the 2014 Regulation for sewage discharged into water or soil $(50 \mathrm{mg} / \mathrm{L})$, as it sporadically exceeded the admissible value (Figure 3). Nevertheless, the removal efficiency values were high for all three organic pollutants: $96.5 \%$ for $\mathrm{BOD}_{5}, 90.8 \%$ for COD and $67.8 \%$ for TSS.
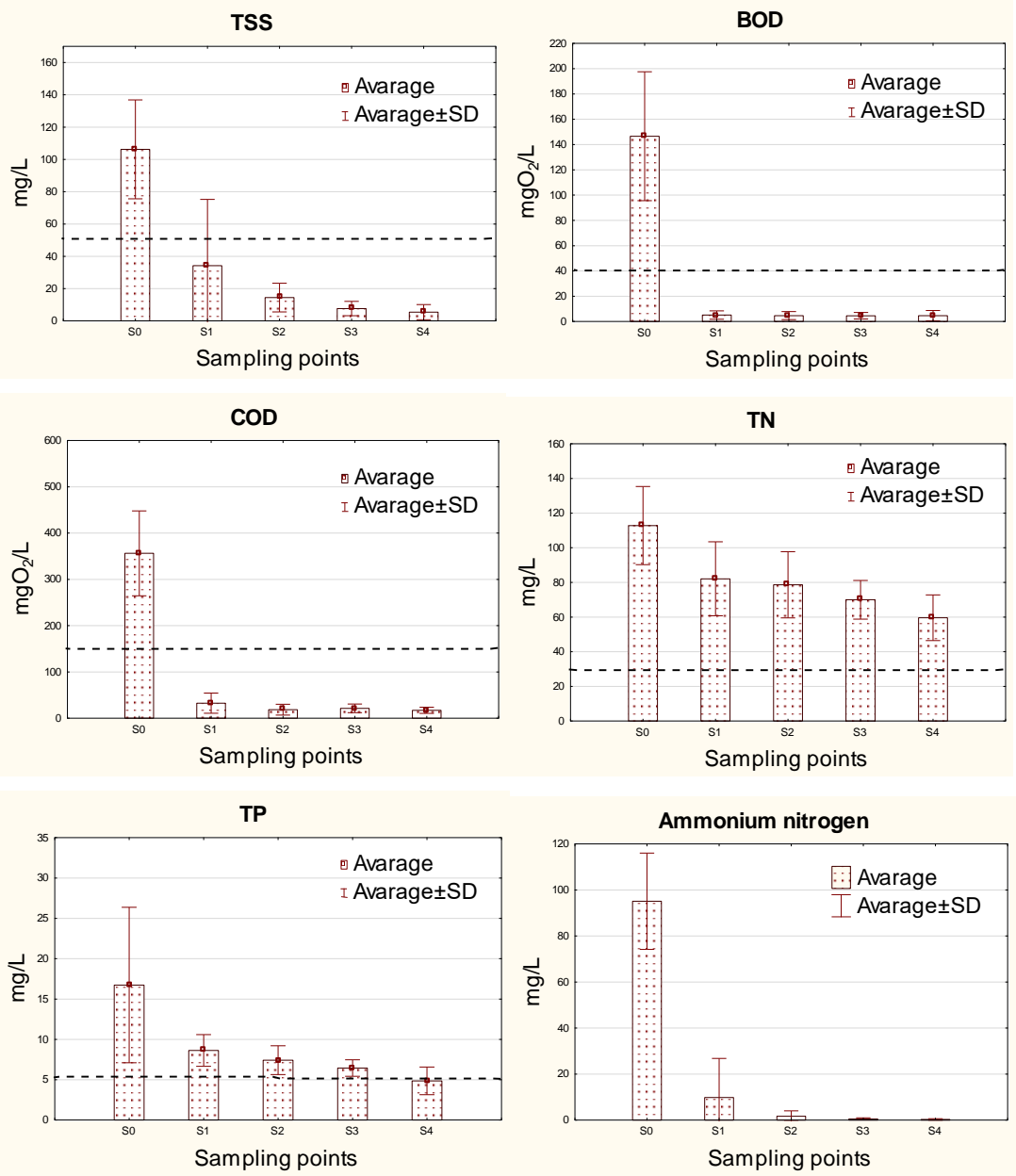

Figure 3. Dynamics of reduction of pollutant concentrations in the successive stages of treatment. Notation: dashed black line-Polish requirements for wastewater discharged into water and soil from treatment plants below 2000 PE [22]. 
In CW systems, organic matter can be mineralized through the biological film that forms on the particles of bed medium and plant roots. Organic substances can decompose under aerobic or anaerobic conditions. Aerobic decomposition is much faster because bacteria that live in the presence of free oxygen (chemoheterotrophs) have much faster metabolism rates than chemoautotrophs [11]. After oxidation of organic compounds, aerobic bacteria use oxygen as the final electron acceptor [1] and release carbon dioxide, ammonia and other stable chemicals. Aerobic decomposition of organic compounds most commonly takes place in SSVF beds, which have much higher oxygenation levels than SSHF beds. This is why, in our study, a significant reduction in organic compounds, expressed as BOD5, COD and TSS, was observed already in the first bed (SSVF with common reed). Intensive biodegradation of organic compounds in soil can also occur without the participation of plants, but in the case of systems with bog vegetation, mineralization of organic contaminants occurs faster and more efficiently as a result of oxygen being supplied to the root zone. In this study, the use of grass (common reed) in the SSVF bed also significantly increased the oxygen content in the bed. The results indicate that the first biological stage of purification provided favorable conditions for the oxidation of organic pollutants and nitrification. The mean oxygen content in the wastewater downstream of the SSVF bed with common reed increased to about $4.7 \mathrm{mg} / \mathrm{L}$, while the mean concentration of ammonium nitrogen, which originally accounted for about $84.3 \%$ of total nitrogen, was $9.84 \mathrm{mg} / \mathrm{L}$. Despite the high efficiency of the reed bed in the removal of ammonium nitrogen, the mean concentration of TN remained rather high at $82.1 \mathrm{mg} / \mathrm{L}$, with values substantially exceeding $100 \mathrm{mg} / \mathrm{L}$. The efficiency of TN removal in this bed was $27.2 \%$. This may mean that a large part of the ammonium nitrogen did not undergo further transformation after it had been converted into the nitrate form. This supposition is confirmed by the high nitrate nitrogen concentrations in the effluent from the first bed-on average $38.1 \mathrm{mg} / \mathrm{L}$ (Table 2). At this stage of treatment, the wastewater also contained high concentrations of TP (a mean of $8.6 \mathrm{mg} / \mathrm{L}$ ). The mean phosphorus removal efficiency of the reed bed was $48.5 \%$. The mean concentrations of the two biogenic indicators were more than double the admissible level stipulated in the Regulation for sewage treatment plants of up to 2000 PE discharging wastewater to standing waters [22].

\subsubsection{Efficiency of SSHF Bed with Salix}

In this bed, only a slight reduction in the concentrations of organic contaminants was observed. $\mathrm{BOD}_{5}$ removal efficiency was merely $8.1 \%$, and COD and TSS removal efficiencies were $43.6 \%$ and $57.7 \%$, respectively. The drastic decrease in the efficiency of removal of organic pollutants could have been caused by the quality of the wastewater flowing into the Salix bed. Most of the pollutant load carried in the influent into the CW had been reduced in the reed bed under aerobic conditions, and so the Salix bed was fed with sewage that contained very low concentrations of contaminants. This may have been associated with the fact that CWs have the ability to accumulate and retain organic matter, as was observed for the SSVF bed with reed. After flowing through the Salix bed, wastewater had the following organic matter parameters: BOD $_{5} 4.7 \mathrm{mg} / \mathrm{L}, \mathrm{COD} 18.5 \mathrm{mg} / \mathrm{L}$ and TSS $14.5 \mathrm{mg} / \mathrm{L}$. These numbers show that organic pollutant concentrations were reduced by half in this bed relative to the values obtained at the outflow from the SSVF bed with common reed. In addition, as shown by the results from the entire study period, TSS concentrations in the effluent from the Salix bed no longer exceeded the admissible value specified by the Polish standards [22]. This means that the use of a two-bed (SSVF-SSHF) system was justifiable. Organic matter accumulating in a CW bed as a result of the constant inflow of sewage, biochemical transformations and the presence of microbial debris is a source of nutrients that are used for further conversion of organic matter [44]. SSHF beds are used in hybrid systems to optimize the removal of nitrogen and organic compounds, mainly due to the anaerobic and hypoxic conditions they provide [11,13]. The horizontal flow of wastewater in the SSHF bed and the use of the Salix reduced the diffusion and transport of oxygen from the atmosphere into the bed. Under the anaerobic conditions found in SSHF beds, organic matter is transformed in the presence of inorganic ions such as $\mathrm{NO}^{3-}, \mathrm{Mn}^{4+}, \mathrm{Fe}^{3+}, \mathrm{SO}_{4}{ }^{2-}$ and $\mathrm{CO}_{2}$, which act as electron acceptors [11,45]. Soil-plant systems, especially hybrid systems consisting of at least two 
beds with different flow modes (vertical and horizontal), are ideal for removing organic pollutants, as confirmed by the present results $\left(\mathrm{BOD}_{5} 4.7 \mathrm{mg} / \mathrm{L}, \mathrm{COD} 18.5 \mathrm{mg} / \mathrm{L}\right)$ as well as reports from other authors $[6,16,31,46-48]$.

The mean concentrations of TN and TP in wastewater treated in the Salix bed $(78.6 \mathrm{mg} / \mathrm{L}$ and $7.4 \mathrm{mg} / \mathrm{L}$ ) did not meet the requirements specified in the 2014 Regulation (Figure 4). The efficiency of this bed in removing biogenic elements was $4.2 \%$ for $\mathrm{TN}$ and $13.9 \%$ for TP. The mean concentration of nitrite nitrogen $(0.16 \mathrm{mg} / \mathrm{L})$ was lower than that found in the effluent from the reed bed $(0.27 \mathrm{mg} / \mathrm{L})$. At the same time, the content of nitrate nitrogen increased to $46.2 \mathrm{mg} / \mathrm{L}$. This rise indicated that nitrification had occurred in this bed; however, given the low concentrations of the pollutants, it is likely that environmental factors, precipitation, temperature or random changes in operating conditions had a much greater impact on the results than nitrification.

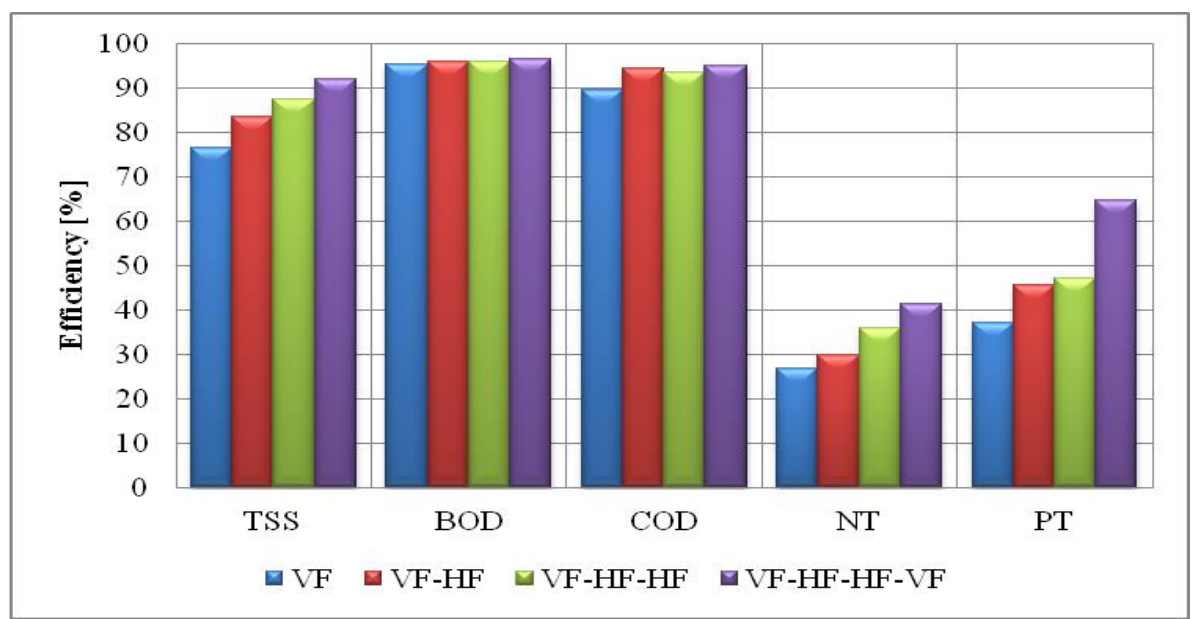

Figure 4. Mean pollutant removal efficiencies in the investigated system.

\subsubsection{Removal Effect in SSHF Bed with Jerusalem Artichoke}

If the results for organic matter alone were considered, it could be argued that the use of the SSHF bed with Jerusalem artichoke was unfounded because the concentrations of organic pollutants were lower than those required by the Polish standards already at the outflow from the SSHF bed with Salix (two-stage system) [22]. However, the use of another bed providing the same conditions as the Salix bed resulted in a further reduction of TN to $70.0 \mathrm{mg} / \mathrm{L}$ and TP to $6.4 \mathrm{mg} / \mathrm{L}$. Jerusalem artichoke, which was used in the second SSHF bed, supplied much smaller amounts of oxygen to the bed than did Salix. Additionally, oxygen diffusion in that bed was reduced due to the horizontal flow of wastewater. The SSHF bed with Jerusalem artichoke provided good conditions for denitrification, enabling a reduction in the nitrate level to $37.1 \mathrm{mg} / \mathrm{L}$ and a two-fold increase in the nitrite concentration to $0.4 \mathrm{mg} / \mathrm{L}$. This bed contributed to a decrease in the TN concentration, as the nitrate form was converted into molecular nitrogen. On this basis, it can be concluded that the construction of the three-stage treatment system was justified from the point of view of reducing the amounts of TN and TP discharged into the environment. As far as the removal of organic contaminants was concerned, the SSHF bed with Jerusalem artichoke showed a low efficiency (BOD $52.5 \%$, COD 16.2\%, TSS 47\%). Actually, the mean COD concentration recorded at the outflow from this bed was higher than that measured at the inflow. This could have been influenced by the fact that organic matter produced in a bog environment accumulates on the surface of the bed and is then transformed, in microbiological processes, into recalcitrant organic substances, such as humic compounds, to create a new soil layer, or into easily decomposable compounds, such as proteins, carbohydrates, and fats $[45,49,50]$. 


\subsubsection{Composition and Quality of Wastewater in Outflow of Constructed Wetland}

The use of the fourth bed allowed us to obtain substantially lower effluent concentrations of pollutants than those specified in Polish standards (BOD $40 \mathrm{mg} / \mathrm{L}, \mathrm{COD}-150 \mathrm{mg} / \mathrm{L}$ and TSS-50 mg/L) (Regulation 2014). Mean BOD 5 was $4.6 \mathrm{mg} / \mathrm{L}, \mathrm{COD}-17.2 \mathrm{mg} / \mathrm{L}$ and TSS $-5.4 \mathrm{mg} / \mathrm{L}$. Again, exceptions were the concentrations of TN $(60.0 \mathrm{mg} / \mathrm{L})$ and TP $(4.9 \mathrm{mg} / \mathrm{L})$. An analysis of the values of the individual organic pollutants given in Figure 3 shows that the only pollution parameter whose concentrations were reduced consistently as the wastewater flowed from one bed to the next was TSS. No such relationship was found for $\mathrm{BOD}_{5}$, the mean concentrations of which at the individual purification stages were as follows: SSVF-SSHF- $4.7 \mathrm{mg} / \mathrm{L}$, SSVF-SSHF-SSHF- $4.6 \mathrm{mg} / \mathrm{L}$, SSVF-SSHF-SSHF-SSVF- $4.6 \mathrm{mg} / \mathrm{L}$. In this case, the use of a four-stage system was unwarranted. The two-stage system provided sufficient protection against the discharge of increased amounts of organic matter, expressed as $\mathrm{BOD}_{5}(>40 \mathrm{mg} / \mathrm{L})$, in the event of a decrease in the efficiency of the SSVF with common reed. Figure 3 shows that the concentrations of $C O D$ in the investigated treatment system were quite low throughout the study period. At no stage of biological treatment was the admissible norm of $150 \mathrm{mg} / \mathrm{L}$ exceeded. Similarly to $\mathrm{BOD}_{5}$, the use of a four-stage system was unjustified in the case of COD. However, the use of a single-stage system over a longer period of time can be risky.

Elimination of nitrogen from wastewater in soil-plant systems, similarly to other treatment plants, is possible due to the transformation of nitrogen compounds in the processes of nitrification and denitrification. It is very important that both processes take place in a treatment plant, otherwise nitrogen will only change its form instead of being released in molecular form. Nitrification can only occur in the presence of oxygen, while denitrification requires anaerobic or oxygen-deficient conditions. This is why authors of numerous scientific publications claim that single-stage soil-plant systems cannot achieve a high nitrogen removal efficiency, since it is impossible for the two processes to occur simultaneously in one bed [13]. The present results confirm this observation. The hybrid set-up with a larger number of beds providing both anaerobic and aerobic conditions showed an improved efficiency in reducing TN and TP.

\subsection{Efficiency of Pollutant Removal in the All CW System}

The test results indicated that the SSVF-SSHF-SSHF-SSVF CW was highly efficient at removing organic impurities (BOD $56 \%$, COD 95\% and TTS 92\%) but much less efficient at eliminating biogenic compounds (TN $41 \%$ and TP $65 \%$ ). At the same time, discernible differences were found between the individual stages of treatment: the basic contaminants were removed much faster in the SSVF with reed than in the SSHF bed with Salix. The first stage of purification (the reed bed) created favorable conditions for the biodegradation of organic pollutants and moderately good conditions for the removal of biogenic contaminants. Several factors may have affected those processes, among others the way the bed was fed with sewage, and determinants directly associated with it, such as the availability of oxygen, hydraulic load and pollutant load of the bed, as well as the plant species used [51,52]. In addition, cyclic dosing of wastewater to the SSVF bed with reed and the alternating occurrence of dry and wet periods may have significantly increased the diffusion of atmospheric oxygen and improved the conditions for the oxidation of organic pollutants and nitrification, as observed in previous research [53,54]. Similar TSS reduction values were obtained by Lesage et al. [39] and Vera et al. [55] in SSVF-SSHF CWs planted with Phragmites australis and Typha latifolia, respectively (87-98\%), and Melián et al. [56] in a hybrid system with Phragmites australis and Scirpus sp. (95\%). Tanner et al. [40] reported a 95\% efficiency of removal of TSS from urban sewage for a three-stage SSHF-SSHF-SSVF system planted with Phragmites australis.

During the three-year study period, the average TSS removal efficiency in the SSVF-SSHFSSHF-SSVF CW ranged from 85.8 to $99.2 \%$ (Figure 4). Data for the individual months show that the highest mean efficiencies were obtained in May (97.4\%) and February (99.2\%). In August and November, the efficiencies were lower at $85.8 \%$ and $86.3 \%$, respectively (Figure 5). This suggests that the air temperature did not have a clear impact on the efficiency of TSS removal in the analyzed 
facility. The three-year air temperature averages for the particular months of the study were as follows: February $4.5^{\circ} \mathrm{C}$, May $14.4^{\circ} \mathrm{C}$, August $18.4^{\circ} \mathrm{C}$ and November $3.7^{\circ} \mathrm{C}$ (Figure 6).
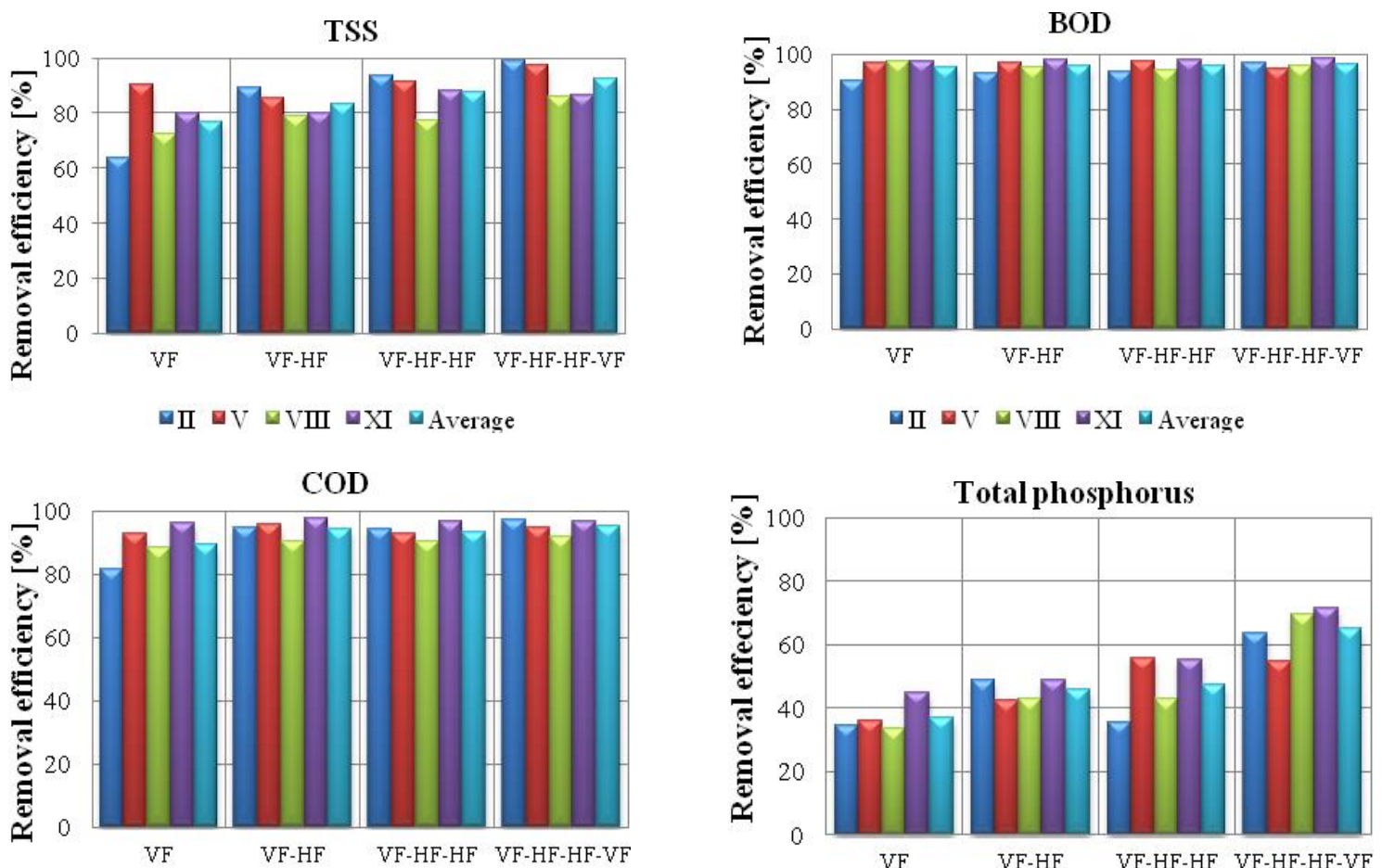

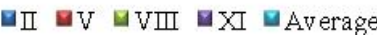

$\square \mathrm{II} \square \mathrm{V} \square \square \mathrm{VX} \square$ Avarage

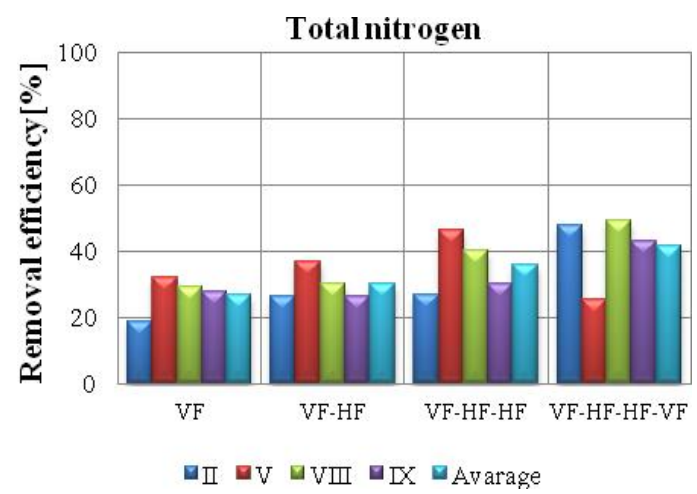

Figure 5. Mean wastewater treatment efficiencies by season.

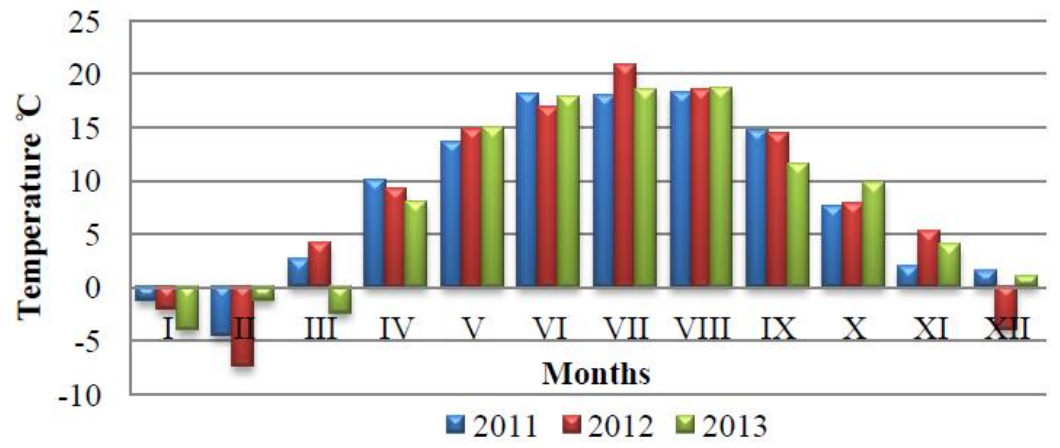

Figure 6. Average monthly temperatures for Radawiec near Lublin, Poland, in the years 2011-2013 [23]. 
To provide a more in-depth analysis of the impact of air temperature on the facility's pollutant removal efficiency, a correlation analysis was carried out using the Pearson correlation test (Table 3). The test showed there were no statistically significant relationships between air temperature and reduced or elevated removal efficiencies for TSS, BOD, COD, TN or TP.

Table 3. Pearson's correlations and the corresponding $p$-values.

\begin{tabular}{cccccc}
\hline & \multicolumn{5}{c}{ Temperature } \\
\hline System & TSS & BOD $_{\mathbf{5}}$ & COD & TN & TP \\
\hline \multirow{2}{*}{ SSVF with common reed } & -0.2521 & 0.3572 & 0.1626 & 0.6094 & 0.4925 \\
& $p=0.482$ & $p=0.385$ & $p=0.701$ & $p=0.081$ & $p=0.178$ \\
\hline \multirow{2}{*}{ SSHF with Salix } & -0.3775 & -0.2426 & -0.0912 & 0.1831 & 0.1899 \\
& $p=0.282$ & $p=0.563$ & $p=0.830$ & $p=0.637$ & $p=0.625$ \\
\hline \multirow{2}{*}{ SSHF with Jerusalem artichoke } & -0.2696 & 0.0053 & -0.6217 & 0.2872 & -0.0943 \\
& $p=0.451$ & $p=0.990$ & $p=0.100$ & $p=0.454$ & $p=0.809$ \\
\hline \multirow{2}{*}{ SSVF with giant miscanthus } & 0.0083 & -0.4600 & -0.6934 & 0.3195 & 0.5418 \\
& $p=0.982$ & $p=0.251$ & $p=0.056$ & $p=0.402$ & $p=0.132$ \\
\hline
\end{tabular}

\subsection{1. $\mathrm{BOD}_{5}$ Removal Effect}

The mean $\mathrm{BOD}_{5}$ removal efficiency in the SSVF-SSHF-SSHF-SSVF wetland ranged from 95.5 to $96.6 \%$ over the three-year study period, depending on the season (Figure 6). A much lower removal efficiency (89\%) for this indicator was found in a SSVF-SSVF-SSHF CW in Japan [57]. CWs located in the Polish villages of Darżlubie (SSHF-SSHF-SSVF-SSHF), Wiklina (SSHF-SSVF-SSHF), Wieszyn (SSHF-SSVF-SSHF) and Schodno (SSHF-SSVF-SSHF-SSVF) were characterized by an average $\mathrm{BOD}_{5}$ removal efficiency of $87 \%$ [9]. Ghrabi et al. [58] analyzed a three-stage SSHF-SSVF-SSHF system with common reed, which had a 97\% BOD 5 reduction efficiency. Tanner et al. [40] reported a 98\% efficiency for an SSHF-SSHF-SSVF facility. Shrestha et al. [59], Rivas et al. [60] and Singh et al. [61] obtained $\mathrm{BOD}_{5}$ removal efficiencies ranging between 97 and 99\% for SSHF-SSVF wetlands.

\subsubsection{COD Removal Effect}

The mean COD removal efficiency in the Dabrowica CW ranged from 89.7 to $95.2 \%$. The highest efficiency was recorded in colder months, i.e., February (97.3\%) and November (96.8\%). In May and August, the efficiency of COD removal dropped to $94.6 \%$ and $92.1 \%$, respectively (Figure 6). Similar values were obtained by Zhai et al. for a SSVF-SSHF system planted with Cyperus alternifolius (94\%) [42]. The same research team recorded a significantly lower efficiency of $84 \%$ for a SSVF-SSHF facility with common reed. In Turkey, Ayaz et al. [62], who studied a SSHF-SSVF CW, found a 95\% COD removal efficiency. Comparable results were obtained by Laber et al. [63], who reported 95 to $98 \%$ removal efficiencies for this parameter in a SSVF-SSHF wetland. The same type of facilities studied by Seo et al. in South Korea [64] and Melián et al. in Spain [56] had COD removal efficiencies of 98\% and $80 \%$, respectively. Vymazal and Kröpfelová [41] reported a mean COD reduction efficiency of $84 \%$ for a SSVF-SSHF wetland located in the Czech Republic. Lesage et al. [39] obtained a 90\% COD removal efficiency for the same kind of two-stage system planted with common reed. Vera et al. [55] reported a 77\% efficiency for a facility with Typha latifolia, and Melián et al. [56] recorded a 83\% efficiency for a wetland with Phragmites australis and Scirpus sp. Ghrabi et al. [58], who investigated a three-stage SSHF-SSHF-SSVF wetland with common reed used for the treatment of urban sewage, recorded a $95 \%$ COD removal efficiency.

\subsubsection{Total Nitrogen Removal Effect}

The three-year mean TN removal efficiency in the Dabrowica CW was $41.35 \%$. The highest efficiency was found in August (49.3\%). Only slightly lower efficiencies were recorded in February 
$(47.9 \%)$ and November (43.1\%), and the lowest efficiencies were measured in May (25.1\%) (Figure 3). Wu et al. [65], who conducted research on nitrogen removal in microcosmic wetland systems planted with four different plant species (Typha orientalis, Phragmites australis, Scirpus validus and Iris pseudacorus) noted a maximum TN removal efficiency of $68 \%$. In an Italian SSVF-SSHF installation planted with reed, TN was removed with an efficiency of $75-78 \%$ [66]. The lowest efficiency of $43 \%$ was reported for a SSVF-SSHF wetland with T. latifolia, located in Spain [55]. In this present study, the SSVF bed with common reed provided favorable conditions for nitrification owing to the intermittent loading of wastewater. The mean TN removal efficiency in this bed was $26.8 \%$, but there was significant seasonal variation (Figure 3). The highest efficiency was recorded in May (31.8\%) and the lowest in February $(18.6 \%)$ and November $(28.0 \%)$. Probably, the differences in efficiency were due to changes in air temperature, which in May averaged $18.5^{\circ} \mathrm{C}$, but dropped to $-5.1^{\circ} \mathrm{C}$ in February and $4.3^{\circ} \mathrm{C}$ in November. It can be concluded from these data that the effectiveness of the SSVF bed with common reed was moderately dependent on air temperature. This is confirmed by the statistical analysis which also points to a relationship between $\mathrm{TN}$ removal efficiency in the reed bed and air temperature. The highest TN removal efficiency reported in the literature so far was recorded in a SSVF bed in China, where the average performance during the spring months was $55.1 \%$ but increased to $79.4 \%$ in the summer [67] Wu et al. [65] also observed a significant correlation between air temperature and the efficiency of TN elimination. Lower temperatures have a decisive influence on the development of rhizosphere microorganisms, which are responsible for the process of nitrification in treatment beds. Furthermore, in winter, an inhibition of plant metabolism causes a reduction in nitrogen assimilation by plants [68]. Gajewska and Obarska-Pempkowiak [31] observed, in a long-term study of five hybrid CWs (HCWs) located in Poland, that total nitrogen removal was ca. 10\% higher in the vegetation season (from May to September). The present study demonstrates that efficient elimination of TN requires the use of a multi-stage $\mathrm{CW}$.

\subsubsection{Phosphorus Reduction}

The wetland in Dabrowica had a mean phosphorus removal efficiency of $64.8 \%$. The best results were obtained in August- $69.3 \%$ and November- $71.6 \%$. The lowest efficiencies were recorded in February-63.5\% and May-54.9\%.

Research shows that the effectiveness of phosphorus removal in HCWs is very high at early stages of operation but decreases after a while due to the loss of sorption capacity by the filter material [69]. Previous worldwide research results showed that the mean phosphorus removal efficiency of wetlands with a SS SSVF bed followed by a SSHF bed ranged from 70 to $89 \%[7,56,57,70,71]$. The mean phosphorus removal efficiency in the SSVF bed with reed was $37.0 \%$. The best performance was observed in November (44.9\%) and May (36\%). In February and August, the efficiencies of phosphorus removal were lower at 34 and 33\%, respectively (Figure 3). To compare, Gizińska et al. [19] recorded a TP removal efficiency of $67.8 \%$ for a SSVF bed with reed.

The efficiency of TP removal in the SSHF bed with Salix ranged between 42 and $48 \%$ during the whole study period. The highest efficiencies were observed in February (49\%) and November $(48 \%)$, and the lowest in August (42\%) and May (43\%). Similar values (48\%) were obtained by Zapater-Pereyra et al. [70] for SSHF reed systems. Leto et al. [72], who studied SSHF beds with two different plant species, recorded TP removal efficiencies of 47.9\% (Typha latifolia) and 31.7\% (Cyperus alternifolius). In their experiments, a control bed without plants reduced the TP load by $14.2 \%$.

The four-stage SSVF-SSHF-SSHF-SSVF wetland allowed to increase the mean TP removal efficiency to $65 \%$. It is difficult to find any dependencies among the individual months of sampling. The lowest efficiencies were found for May (55\%) and the highest for August (69\%). This suggests that the lower efficiency may have been due to the fact that in May the plants had only just began to grow. In August, the plants were in full flush, which may have been why the efficiencies were higher.

The four-stage system fulfilled its role perfectly in the case of TSS reduction, with removal efficiencies increasing as wastewater flowed from one bed to the next: 76\% (SSVF), 83\% (SSVF-SSHF), 
87\% (SSVF-SSHF-SSHF) and 92\% (SSVF-SSHF-SSHF-SSVF) (Figure 4). The same relationship was observed for the biogenic elements TN and TP. The removal efficiencies for TN in the individual stages of treatment in the investigated wetland were 27\% (SSVF), 30\% (SSVF-SSHF), $36 \%$ (SSVF-SSHF-SSHF) and 41\% (SSVF-SSHF-SSHF-SSVF), and those for TP were 37\% (SSVF), $46 \%$ (SSVF-SSHF), 47\% (SSVF-SSHF-SSHF) and 65\% (SSVF-SSHF-SSHF-SSVF). These results demonstrate that the use of a four-stage system significantly improves the efficiency of removal of biogenic elements from wastewater. The only indicators that remained unaffected by the use of the larger number of beds were $\mathrm{COD}$ and $\mathrm{BOD}_{5}$.

By comparing the values presented in Table 4 to the yield of harvested plant biomass, one can determine the role of plants in removing biogenic elements (the approximate amounts of the individual biogenic components taken up by plants). A measure that can be used for this purpose is the mass removal rate (MRR), which relates the amount of a component removed to the unit of surface area of a CW system. Table 4 compares the theoretical MRR values (calculated using formula (2)) for the main contaminants for each bed and for the entire SSVF-SSHF-SSHF-SSVF system.

Table 4. Mass removal rates (MRR) of $\mathrm{BOD}_{5}, \mathrm{COD}, \mathrm{TN}$ and $\mathrm{TP}$.

\begin{tabular}{|c|c|c|c|c|c|}
\hline & & $\begin{array}{l}\text { SSVF with } \\
\text { Reed }\end{array}$ & $\begin{array}{l}\text { SSHF with } \\
\text { Salix }\end{array}$ & $\begin{array}{l}\text { SSHF with } \\
\text { Jerusalem } \\
\text { Artichoke }\end{array}$ & $\begin{array}{l}\text { SSVF with } \\
\text { Giant } \\
\text { Miscanthus }\end{array}$ \\
\hline \multirow{2}{*}{ TSS } & $\begin{array}{c}\text { Load } \\
\text { (g/m²/day) }\end{array}$ & 2.65 & 1.32 & 0.88 & 0.66 \\
\hline & $\begin{array}{c}\text { MRR } \\
\text { (g/m²/day) }\end{array}$ & 1.80 & 1.15 & 0.82 & 0.63 \\
\hline \multirow{2}{*}{$\mathrm{BOD}_{5}$} & $\begin{array}{c}\text { Load } \\
\left(\mathrm{g} / \mathrm{m}^{2} / \text { day }\right)\end{array}$ & 3.66 & 1.83 & 1.22 & 0.92 \\
\hline & $\begin{array}{c}\text { MRR } \\
\text { (g/m²/day) }\end{array}$ & 3.54 & 1.77 & 1.18 & 0.89 \\
\hline \multirow{2}{*}{ COD } & $\begin{array}{c}\text { Load } \\
\text { (g/m²/day) }\end{array}$ & 8.91 & 4.45 & 2.97 & 2.23 \\
\hline & $\begin{array}{c}\text { MRR } \\
\text { (g/m²/day) }\end{array}$ & 8.09 & 4.22 & 2.79 & 2.12 \\
\hline \multirow{2}{*}{$\mathrm{TN}$} & $\begin{array}{c}\text { Load } \\
\text { (g/m²/day) }\end{array}$ & 2.82 & 1.41 & 0.94 & 0.705 \\
\hline & $\begin{array}{c}\text { MRR } \\
\text { (g/m²/day) }\end{array}$ & 0.76 & 0.85 & 0.44 & 0.703 \\
\hline \multirow{2}{*}{ TP } & $\begin{array}{c}\text { Load } \\
\text { (g/m²/day) }\end{array}$ & 0.42 & 0.21 & 0.14 & 0.10 \\
\hline & $\begin{array}{c}\text { MRR } \\
\left(\mathrm{g} / \mathrm{m}^{2} / \text { day }\right)\end{array}$ & 0.20 & 0.12 & 0.09 & 0.07 \\
\hline
\end{tabular}

The participation of plant uptake in the removal of contaminants from wastewater, expressed as the content of nitrogen and phosphorus in biomass, was relatively small (Table 4). The mean weight of biogenic elements in the total reed crop was $0.23 \mathrm{~kg} \mathrm{~N}$ and $0.02 \mathrm{~kg}$ P. This means that in the first bed, reed accumulated $7 \%$ of the $\mathrm{N}$ load and $2.3 \%$ of the $\mathrm{P}$ load removed in this bed during the six-month growing season (April-October). Similar results were recorded for Salix, for which the contents of nitrogen and phosphorus accumulated in the aerial plant parts were $0.15 \mathrm{~kg}$ and $0.2 \mathrm{~kg}$, respectively.

The lowest amounts of the biogenic elements were accumulated in Jerusalem artichoke- $0.08 \mathrm{~kg}$ $\mathrm{N}$ and $0.01 \mathrm{~kg} \mathrm{P}$ - and giant miscanthus $-0.06 \mathrm{~kg} \mathrm{~N}$ and $0.01 \mathrm{~kg}$ P. Those values represented $1.7 \%$ of the mean $\mathrm{N}$ load and $1.8 \%$ of the mean P load removed in the SSHF bed with Jerusalem artichoke and $1 \% \mathrm{~N}$ and $8.3 \% \mathrm{P}$ eliminated in the SSVF with giant miscanthus.

The differences in nutrient removal efficiencies were not as large as those reported by other authors. This mainly concerns nitrogen transformations, the intensity of which is strongly related to 
temperature [11,73]. In the present study, nitrogen removal may have been substantially affected by physicochemical processes such as oxidation or adsorption by bed material [11,74]. Physicochemical processes, and in particular sorption by bed particles, may have also influenced the elimination of phosphorus from wastewater [3].

It is important to note that the values of the biogenic components were determined assuming that the average annual sewage discharge from the individual stages of the treatment plant was equal to the average annual incoming wastewater. In real-life conditions, however, these values may differ to a greater or lesser extent, which is primarily influenced by evapotranspiration and precipitation [75,76]). Evapotranspiration efficiency in CWs is subject to large fluctuations: depending on the season, it can range from 0 to $50 \mathrm{~mm} /$ day [76]. According to Herbst and Kappen [77], who studied a reed belt around a lake in northern Germany, evapotranspiration may exceed $10 \mathrm{~mm} /$ day in the full growing season, but can drop to nearly zero in other periods (from November to April). These researchers also found that under certain conditions (cloudy and rainy weather), annual evapotranspiration efficiency may be similar to, or even lower than, total annual precipitation. Chazarenc et al. [75], in their study of a SSHF bed that was part of a multi-stage CW, observed that evapotranspiration from beds could be largely balanced by atmospheric precipitation. In the case of the Dabrowica sewage treatment plant, evapotranspiration efficiency may have been limited by the vicinity of high-tree stands on the southwest side of the facility, which periodically shaded the beds and restricted air movement. A study by Toscano et al. [78] also indicates that evapotranspiration efficiency of beds with giant miscanthus located in warm climate is distinctly lower than that of reed beds.

The four-stage wetland analyzed in this present study had an organics removal efficiency similar to other systems with "traditional" plant species. This means that the use of the giant miscanthus and the Jerusalem artichoke did not significantly increase the performance of this facility. Indeed, plants used in CWs are only intended to support wastewater treatment by creating favorable conditions for the activity of microorganisms and for biochemical transformations [79-81]. This is confirmed by the present results, including those pointing to a lack of clear differences in efficiency values at different times of the year. In the case of both the individual beds and the entire wasteland, no significant relationship was observed between increases or decreases in efficiency and the individual seasons. Most efficiency values remained similar throughout the study period. In situations where there were visible declines in efficiency, they were not connected to seasonal changes in the weather. In the case of TSS and COD, the CW showed a higher efficiency in spring and winter, and in the case of $\mathrm{BOD}_{5}$-in autumn and winter. Most researchers report an inverse relationship [11,73], and some report no differences in the removal of these compounds between summer and winter [74]. The lack of a clear impact of seasonal conditions on microbiological removal processes can be associated with the intensity of the physical processes. In addition, Ouellet Plamondon et al. [82] claim that favorable oxygen conditions may offset the relationship between the kinetics of biological reactions and temperature in a colder climate. The mean nitrogen and phosphorus removal efficiencies were slightly higher in August and November compared to the other sampling months. However, also in this case, there did not seem to exist a significant correlation between efficiency and seasonal temperature changes.

\subsection{Pollutant Removal Reliability}

The reliability of a wastewater treatment plant can be defined as its ability to treat a specific amount of wastewater to a purity level that meets the requirements for the receiving body. In the present study, reliability was determined using the Weibull method, which allows to analyze data, with reference to applicable legal requirements, more accurately than the use of mean values. In the first step, the distribution parameters were estimated, and the null hypothesis that empirical data could be described by the Weibull distribution was tested. Data sets included the levels of BOD 5 , COD, TSS, total nitrogen and total phosphorus in wastewater discharged from the SSVF-SSHF-SSHF-SSVF system to a receiving body. The null hypothesis was supported, and the results of the Hollander-Proschan goodness-of-fit test along with the estimated parameters are shown in Table 5. 
Table 5. Parameters of the Weibull distribution and the Hollander-Proschan goodness-of-fit test.

\begin{tabular}{cccccc}
\hline \multirow{2}{*}{ Parameter } & \multicolumn{2}{c}{ Parameters of Weibull Distribution } & \multicolumn{2}{c}{$\begin{array}{c}\text { Hollander-Proschan } \\
\text { Goodness-of-Fit Test }\end{array}$} \\
\cline { 2 - 6 } & $\boldsymbol{\theta}$ & $\boldsymbol{c}$ & $\boldsymbol{b}$ & stat & $\boldsymbol{p}$ \\
\hline BOD $_{5}$ & 0.2151 & 1.2213 & 4.9595 & 0.1420 & 0.8870 \\
COD & -1.0000 & 2.8239 & 18.4340 & -0.1047 & 0.9165 \\
TSS & 0.6606 & 1.3697 & 6.0458 & 0.1876 & 0.8511 \\
Total Nitrogen & 25.9090 & 5.1395 & 64.7720 & 0.1636 & 0.8700 \\
Total Phosphorus & 2.0808 & 3.1134 & 5.4310 & 0.2207 & 0.8253 \\
\hline
\end{tabular}

Symbols: stat-value of the test statistic, $p$-significance level of the test; when $p \leq 0.05$ the data do not follow a Weibull distribution.

The goodness-of-fit of the distributions was high at 82-91\%, significance level $\alpha=0.05$.

The technological reliability of the treatment plant was determined based on distribution functions, taking into account the discharge limits set in the Regulation of the Polish Minister of the Environment for treatment plants representing less than 2000 PE [22] (Figure 7). Statistical analysis demonstrated that the SSVF-SSHF-SSHF-SSVF constructed wetland was 100\% reliable at removing organic pollutants, i.e., $\mathrm{BOD}_{5}, \mathrm{COD}$ and TSS (Figure 7). On this basis, it can be concluded that the investigated facility worked flawlessly throughout the entire study period. During the three years of observation, none of the above-mentioned parameters exceeded the discharge limits prescribed by Polish law, i.e., $40 \mathrm{mgO}_{2} / \mathrm{L}-\mathrm{BOD}_{5}, 50 \mathrm{mg} / \mathrm{L}-\mathrm{TSS}$ and $150 \mathrm{mgO}_{2} / \mathrm{L}-\mathrm{COD}$. This shows that, at the operator's risk of $\alpha=0.05$, the facility would have successfully passed inspection with regard to the parameters concerned throughout the year.

Compared to organic pollutants, the reliability of removal of biogenic compounds was much lower. The probability that the concentration of total nitrogen in treated wastewater would reach the limit $(30 \mathrm{mg} / \mathrm{L})$ set for wastewater discharged to stagnant waters from wastewater treatment plants of less than $2000 \mathrm{PE}$ was $2 \%$. This means that the concentration of nitrogen in the effluent exceeded the discharge limit, and the SSVF-SSHF-SSHF-SSVF system operated incorrectly on $358 \mathrm{~d}$ of the year. According to the guidelines proposed by Andraka and Dzienis [83], the minimum level of reliability for sewage treatment plants of less than $2000 \mathrm{PE}$ is $97.27 \%$, which means that these plants, even when operating poorly for $9 \mathrm{~d}$ a year, still have a $95 \%$ chance of successfully going through inspection procedures. Given these guidelines, the excessive concentrations of total nitrogen in wastewater discharged from the investigated treatment plant could potentially lead to a failed inspection on $349 \mathrm{~d}$ of the year.

A much higher level of reliability was obtained for the removal of total phosphorus. The exceedance probability for this parameter (maximum discharge limit $5 \mathrm{mg} / \mathrm{L}$ ) was $54 \%$. This result indicates that the wastewater treatment plant operated properly on $197 \mathrm{~d}$ of the year, and excessive concentrations of total phosphorus in the effluent could potentially lead to a failed inspection on $159 \mathrm{~d}$ of the year. 

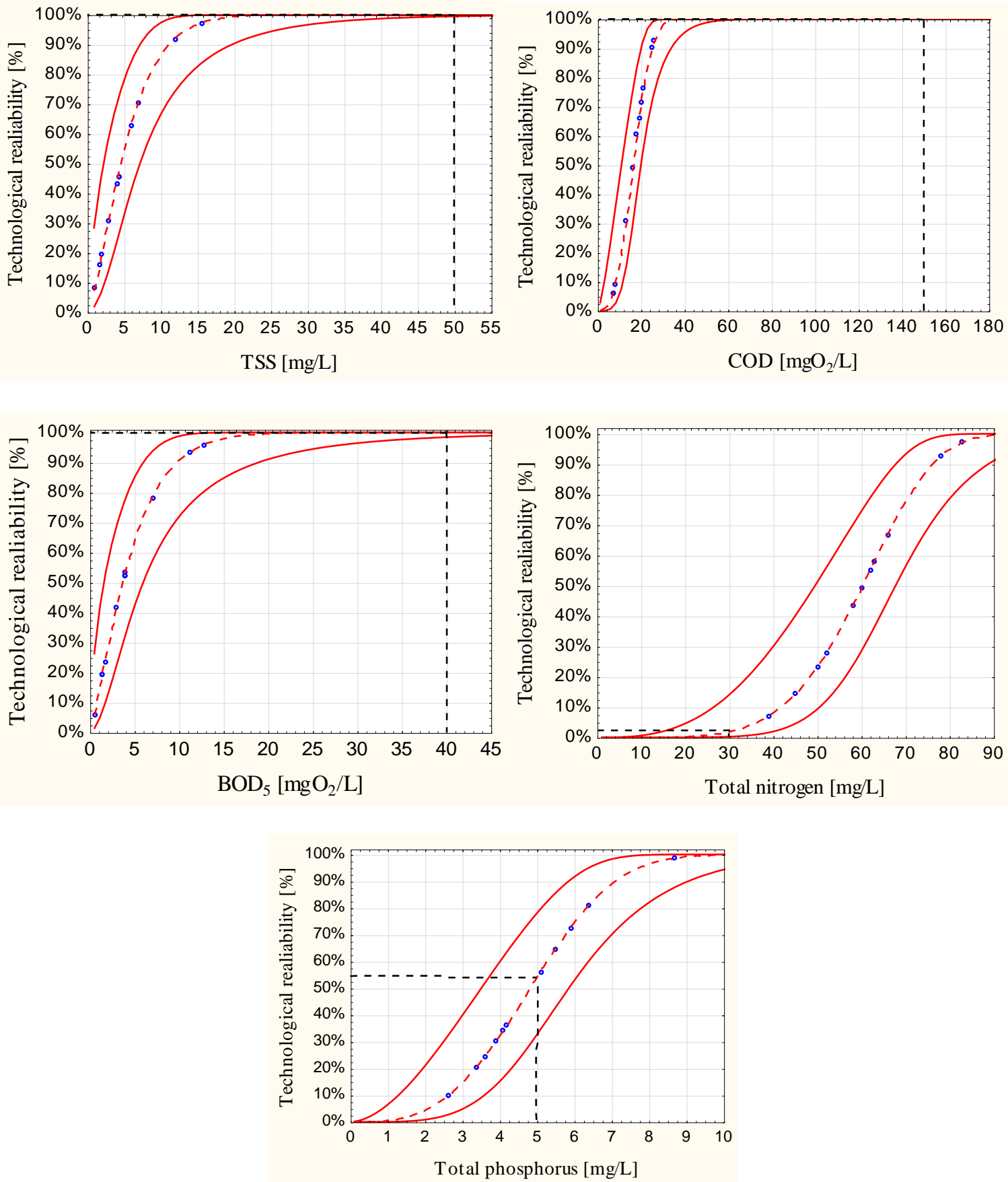

Figure 7. Weibull cumulative distribution functions and the technological reliabilities determined for each pollution parameter. Notation: dashed red line-reliability function, dashed black line-probability of achieving the indicators limit in the effluent.

The reliability levels calculated in this study indicate that the treatment plant showed excellent performance when it comes to removing organic pollutants. Throughout the study period, wastewater discharged from the facility contained stable, low concentrations of $\mathrm{BOD}_{5}$, TSS and COD. Reports by other authors confirm that constructed wetlands provide a high degree of reliability with regard to the removal of organic pollutants $[4,35,51,52]$. The reliability of the SSVF-SSHF-SSHF-SSVF constructed wetland was higher than reliabilities reported for single-stage systems [3,4] and similar to those reported for two-stage systems [51,52]. In facilities using other technological solutions for wastewater treatment, such as activated sludge, a biological filter bed or a hybrid reactor, removal reliability levels 
for organic pollutants expressed by $\mathrm{BOD}_{5}$ and COD ranged between 60 and $88 \%$ as well as 89 and $92 \%$, respectively, and in some extreme cases were as low as 30\% [33,84,85].

The reliability of nutrient removal treatment was $54 \%$ for total phosphorus and $2 \%$ for total nitrogen. These values indicate that the probability of exceedance of the load of these biogenic compounds in the effluent was high. The reliability levels we obtained were lower even than those recorded for single-stage constructed wetlands [3]. A clearly higher level of reliability of nitrogen removal treatment $(32 \%)$ was obtained for a hybrid system by Marzec and colleagues [51,52]. However, compared to the wetland analyzed in this present article, the SSVF-SSHF plant they studied had a significantly lower reliability of total phosphorus removal treatment (28\%). Considerably higher nutrient removal reliabilities were obtained for a hybrid treatment plant by Jucherski et al. [35]: 76.8\% for total nitrogen and $95.2 \%$ for total phosphorus.

Of note, pursuant to Polish law, the concentration of nutrients is subject to assessment only when the effluent is discharged into lakes and their tributaries, as well as directly into artificial water reservoirs situated on flowing waters [22]. In addition, there is no obligation to monitor the operation of domestic wastewater treatment plants and carry out qualitative tests of their discharges into the environment. This notwithstanding, reliability tests carried out in randomly selected facilities in conjunction with the analysis of the efficiency of those treatment plants allow to determine what technological solutions perform best from the point of view of protecting waters against pollution. Results of such studies may help limit the use of the cheapest solutions, which instead of protecting the environment pose a potential threat to it $[2,3,85]$.

\section{Conclusions}

The SSVF bed with common reed used in the first stage of treatment provided favorable conditions for the biodegradation of organic pollutants and moderately good conditions for the removal of biogenic pollutants. Several factors may have played an important role here, among others the way the bed was fed with sewage and the determinants directly associated with it, such as the availability of oxygen, the hydraulic load and the pollutant load of the bed, the plant species used, and air and sewage temperatures.

In addition, cyclic dosing of wastewater to the reed bed and alternating occurrence of dry and wet periods may have significantly increased the diffusion of atmospheric oxygen and improved the conditions for oxidation of organic pollutants and nitrification, as suggested by other authors.

The use of the four-stage SSVF-SSHF-SSHF-SSVF treatment system generally improved the efficiency of removal of TSS, $\mathrm{BOD}_{5}$ and COD, compared to systems with fewer beds. In the case of the biogenic elements TN and TP, the removal efficiency increased as wastewater passed from one bed to the next.

In the temperate climate of Poland, the multi-stage system provided a high and stable efficiency of removing organic pollutants throughout the year. On average, over $96 \%$ of the organic pollutant load $\left(\mathrm{BOD}_{5}\right.$ and $\left.\mathrm{COD}\right)$ flowing in with wastewater was removed in the first bed. Biodegradation of organic pollutants in this bed was probably promoted by the operating conditions, including periodic feeding of the bed with large wastewater batches and the use of common reed. The average $\mathrm{BOD}_{5}, \mathrm{COD}$ and TSS values in wastewater discharged to the receiver were considerably lower than the limits specified in the 2014 Regulation. Admissible concentrations of these pollutants were found already after the first stage of treatment in samples collected downstream of the SSVF bed with common reed. However, these concentrations were further reduced as wastewater flowed through the subsequent beds.

The removal efficiencies for TN and TP were relatively low ( $41 \%$ and $65 \%$, respectively), and the mean contents of these components in the effluent from the treatment plant exceeded the admissible levels. The low TN removal efficiency may have been associated with the lack of proper conditions for denitrification in the SSHF bed with Salix, including the deficit of organic compounds. All the same, the use of the four-stage system resulted in a significant increase in the efficiency of removal of biogenic compounds compared to traditional two-stage systems. 
Reliability assessments of domestic wastewater treatment plants allow to determine what technological solutions are optimal from the point of view of environmental protection, and they should be an important element of planning sanitation infrastructure in rural areas.

The investigated SSVF-SSHF-SSHF-SSVF constructed wetland was 100\% reliable at removing $\mathrm{BOD}_{5}, \mathrm{COD}$ and TSS, a result that was similar to the levels recorded for two-stage systems. In the given operational conditions, the facility ensures problem-free operation and meets Polish discharge limits throughout the year at a low operator's risk. The reliability of total phosphorus and total nitrogen removal was $54 \%$ and $2 \%$, respectively. These results indicate that the probability of exceedance of the load of these nutrients in the effluent was high.

The giant miscanthus and the Jerusalem artichoke showed features that were beneficial from the point of view of the use of these plants in CWs in a temperate climate.

This paper was written as part of the project entitled "Wastewater treatment and the infrastructure of rural areas" financed by the Polish Ministry of Science and Higher Education.

Author Contributions: Conceptualization, M.G.-G., M.M. and K.J. Data curation, M.M., M.G.-G. Formal analysis, M.M. Investigation, M.G.-G. and K.J. Methodology, K.J. Resources, M.G.-G. Supervision, M.M. Validation, K.J. Writing-original draft, M.G.-G. and K.J. Writing-review and editing, M.M. and M.G.-G. All authors have read and agreed to the published version of the manuscript.

Funding: Funding support from the Ministry of Science and Higher Education Republic of Poland for the project entitled "Wastewater treatment and rural areas infrastructure" (contract No. TKD/DS/1, 2010-14) is gratefully acknowledged.

Conflicts of Interest: The authors declare no conflict of interest.

\section{References}

1. García, J.A.; Paredes, D.; Cubillos, J.A. Effect of plants and the combination of wetland treatment type systems on pathogen removal in tropical climate conditions. Ecol. Eng. 2013, 58, 57-62. [CrossRef]

2. Jóźwiakowski, K.; Mucha, Z.; Generowicz, A.; Baran, S.; Bielińska, J.; Wójcik, W. The use of multi-criteria analysis for selection of technology for a household WWTP compatible with sustainable development/Zastosowanie analizy wielokryterialnej do wyboru rozwiazania technologicznego przydomowej oczyszczalni ścieków zgodnego z idea zrównoważonego rozwoju. Arch. Environ. Prot. 2015, 41, 76-82. [CrossRef]

3. Jóźwiakowski, K.; Bugajski, P.; Kurek, K.; Fátima Nunes de Carvalho, M.; Adelaide Almeida, M.; Siwiec, T.; Borowski, G.; Czekała, W.; Dach, J.; Gajewska, M. The efficiency and technological reliability of biogenic compounds removal during long-term operation of a one-stage subsurface horizontal flow constructed wetland. Sep. Purif. Technol. 2018, 202, 216-226. [CrossRef]

4. Jóźwiakowski, K. Studies on the efficiency of sewage treatment in chosen constructed wetland systems. Infr. Ecol. Rural Areas 2012, 1, 232. (In Polish)

5. Jóźwiakowski, K.; Dach, J.; Kowalczyk-Juśko, A.; Marzec, M.; Gizińska, M.; Pytka, A.; Skwarzyńska, A. Eco-logistics aspects of the construction and exploitation of the ground plant systems for wastewater purification and simultaneous production of biomass for energy purposes. Logistyka 2014, 6, 102-107.

6. Vymazal, J. Constructed Wetlands for Wastewater Treatment: Five Decades of Experience ${ }^{\dagger}$. Environ. Sci. Technol. 2011, 45, 61-69. [CrossRef]

7. Vymazal, J. The use of hybrid constructed wetlands for wastewater treatment with special attention to nitrogen removal: A review of a recent development. Water Res. 2013, 47, 4795-4811. [CrossRef]

8. Vymazal, J.; Kröpfelová, L. Types of Constructed Wetlands for Wastewater Treatment. In Wastewater Treatment in Constructed Wetlands with Horizontal Sub-Surface Flow; Springer Science and Business Media LLC: Berlin, Germany, 2008; Volume 14, pp. 121-202.

9. Gajewska, M.; Obarska-Pempkowiak, H. 20 lat doświadczeń z eksploatacji oczyszczalni hydrofitowych w Polsce. Rocznik Ochrony Srodowiska 2009, 11, 875-888.

10. Cui, L.; Ouyang, Y.; Lou, Q.; Yang, F.; Chen, Y.; Zhu, W.; Luo, S. Removal of nutrients from wastewater with Canna indica L. under different vertical-flow constructed wetland conditions. Ecol. Eng. 2010, 36, 1083-1088. [CrossRef] 
11. Saeed, T.; Sun, G. A review on nitrogen and organics removal mechanisms in subsurface flow constructed wetlands: Dependency on environmental parameters, operating conditions and supporting media. J. Environ. Manag. 2012, 112, 429-448. [CrossRef] [PubMed]

12. Faulwetter, J.L.; Gagnon, V.; Sundberg, C.; Chazarenc, F.; Burr, M.D.; Brisson, J.; Camper, A.K.; Stein, O.R. Microbial processes influencing performance of treatment wetlands: A review. Ecol. Eng. 2009, 35, 987-1004. [CrossRef]

13. Vymazal, J. Removal of nutrients in various types of constructed wetlands. Sci. Total Environ. 2007, 380, 48-65. [CrossRef] [PubMed]

14. Chen, Y.; Wen, Y.; Cheng, J.; Xue, C.; Yang, D.; Zhou, Q. Effects of dissolved oxygen on extracellular enzymes activities and transformation of carbon sources from plant biomass: Implications for denitrification in constructed wetlands. Bioresour. Technol. 2011, 102, 2433-2440. [CrossRef]

15. Meng, P.; Pei, H.; Hu, W.; Shao, Y.; Li, Z. How to increase microbial degradation in constructed wetlands: Influencing factors and improvement measures. Bioresour. Technol. 2014, 157, 316-326. [CrossRef] [PubMed]

16. Vymazal, J.; Březinová, T. Long term treatment performance of constructed wetlands for wastewater treatment in mountain areas: Four case studies from the Czech Republic. Ecol. Eng. 2014, 71, 578-583. [CrossRef]

17. Wu, H.; Zhang, J.; Ngo, H.H.; Guo, W.; Shuang, L.; Liang, S.; Fan, J.; Liu, H. A review on the sustainability of constructed wetlands for wastewater treatment: Design and operation. Bioresour. Technol. 2015, 175, 594-601. [CrossRef]

18. Yan, Y.; Xu, J. Improving Winter Performance of Constructed Wetlands for Wastewater Treatment in Northern China: A Review. Wetlands 2014, 34, 243-253. [CrossRef]

19. Gizińska, M.; Jóźwiakowski, K.; Kowalczyk-Juśko, A.; Pytka, A.; Marzec, M. Biomass productivity and biomass energy properties of plants of hybrid constructed wetland wastewater treatment plant in the first year of operations. Gaz Woda Technika Sanitarna 2013, 7, 280-284. (In Polish)

20. Conley, L.M.; Dick, R.L.; Lion, L.W. An Assesment of the root zone method of wastewater treatment. Res. J. WPCF 1991, 63, 239-247.

21. Institute of Meteorology and Water Management (IMWM). Average Monthly Air Temperatures and Monthly Rainfall for the Station in Radawiec Near Lublin. 2018. Available online: https:/dane.imgw.pl/data/dane_ pomiarowo_obserwacyjne/ (accessed on 5 May 2020). (In Polish).

22. Regulation of the Minister of the Environment. Polish Standards according Limits for Discharged Sewage and Environmental Protection from 18 November 2014 (No 2014 item 1800). 2014. Available online: http://prawo.sejm.gov.pl/isap.nsf/download.xsp/WDU20140001800/O/D20141800.pdf (accessed on 2 May 2020). (In Polish)

23. PN-74/C-04620/00. Water and Sewage-Sampling-General Provision and Scope of the Standard; Polski Komitet Normalizacji, Miar i Jakości: Warszawa, Poland, 1975. (In Polish)

24. PN-EN 25667-2. Water Quality—Sampling—Guidance on Sampling Techniques; Polski Komitet Normalizacyjny: Warszawa, Poland, 1999. (In Polish)

25. PN-EN 1899-1:2002. Water Quality—Determination of Biochemical Oxygen Demand after $n$ Days (BOD)—Part 1: Dilution and Vaccination Method with the Addition of Allythiourea; Polski Komitet Normalizacyjny: Warszawa, Poland, 2002. (In Polish)

26. PN-EN 872:2007. Water Quality_Determination of Suspended Solids-Method by Filtration trough Filters; Polski Komitet Normalizacyjny: Warszawa, Poland, 2007. (In Polish)

27. PN-EN ISO 6878:2006P. Water Quality—Determination of Phosphorus-Ammonium Molybdate Spectrometric Method; Polski Komitet Normalizacyjny: Warszawa, Poland, 2006. (In Polish)

28. PN-ISO 15705:2005. Water Quality—Determination of the Chemical Oxygen Demand Index (ST-COD)—Small-Scale Sealed-Tube Method; Polski Komitet Normalizacyjny: Warszawa, Poland, 2005. (In Polish)

29. PN-EN ISO 6869:2002. Feed-Determination of Phosphorus Content-Spectrometric Method; Polski Komitet Normalizacyjny: Warszawa, Poland, 2007. (In Polish)

30. American Public Health Association (APHA). Standard Methods for Examination of Water and Wastewater, 21st ed.; American Public Health Association: Washington, DC, USA, 2005.

31. Gajewska, M.; Obarska-Pempkowiak, H. Efficiency of pollutant removal by five multistage constructed wetlands in a temperate climate. Environ. Prot. Eng. 2011, 37, 27-36.

32. Heidrich, Z.; Kalenik, M.; Podedworna, J.; Stańko, G. Sanitation of the Village; Wydawnictwo Seidel-Przywecki: Warszawa, Poland, 2008; Volume 374, ISBN 978-83-60956-04-5. (In Polish) 
33. Bugajski, P.; Wałega, A.; Kaczor, G. Application of the Weibull reliability analysis of haousehold sewage treatment plant. Gaz Woda Technika Sanitarna 2012, 2, 56-58. (In Polish)

34. Bugajski, P. Analysis of reliability of the treatment plant Bioblok PS-50 using the method of Weibull. Infra. Ecol. Rural Areas 2014, 2, 667-677.

35. Jucherski, A.; Nastawny, M.; Walczowski, A.; Jóźwiakowski, K.; Gajewska, M. Assessment of the technological reliability of a hybrid constructed wetland for wastewater treatment in a mountain eco-tourist farm in Poland. Water Sci. Technol. 2017, 75, 2649-2658. [CrossRef] [PubMed]

36. Bugajski, P.; Bergel, T. Values of selected concentrations of pollutants in domestic sewage exiting the countryside. Gaz Woda Tech. Sanit. 2008, 9, 28-29. (In Polish)

37. Bugajski, P.; Chmielowski, K.; Kaczor, G. Optimizing the Percentage of Sewage from Septic Tanks for Stable Operation of a Wastewater Treatment Plant. Pol. J. Environ. Stud. 2016, 25, 1421-1425. [CrossRef]

38. Abidi, S.; Kallali, H.; Jedidi, N.; Bouzaiane, O.; Hassen, A. Comparative pilot study of the performances of two constructed wetland wastewater treatment hybrid systems. Desalination 2009, 246, 370-377. [CrossRef]

39. Lesage, E.; Rousseau, D.P.L.; Meers, E.; Van De Moortel, A.M.K.; Du Laing, G.; Tack, F.M.; De Pauw, N.; Verloo, M.G. Accumulation of Metals in the Sediment and Reed Biomass of a Combined Constructed Wetland Treating Domestic Wastewater. Water Air Soil Pollut. 2007, 183, 253-264. [CrossRef]

40. Tanner, C.C.; Sukias, J.P.S.; Headley, T.R.; Yates, C.R.; Stott, R. Constructed wetlands and denitrifying bioreactors for on-site and decentralized wastewater treatment: Comparison of five alternative configurations. Ecol. Eng. 2012, 42, 112-123. [CrossRef]

41. Vymazal, J.; Kröpfelová, L. A three-stage experimental constructed wetland for treatment of domestic sewage: First 2 years of operation. Ecol. Eng. 2011, 37, 90-98. [CrossRef]

42. Zhai, J.; Xiao, H.W.; Kujawa-Roeleveld, K.; He, Q.; Kerstens, S.M. Experimental study of a novel hybrid constructed wetland for water reuse and its application in Southern China. Water Sci. Technol. 2011, 64, 2177-2184. [CrossRef]

43. Gikas, G.D.; Tsihrintzis, V.A. A small-size vertical flow constructed wetland for on-site treatment of household wastewater. Ecol. Eng. 2012, 44, 337-343. [CrossRef]

44. Vymazal, J. Removal of Organics in Czech Constructed Wetlands with Horizontal Sub-Surface Flow. In Transformations of Nutrients in Natural and Constructed Wetlands; Backhuys Publishers: Leiden, The Netherlands, 2001; pp. 305-327.

45. Kadlec, R.H.; Wallace, S. Treatment Wetlands, 2nd ed.; CRC Press Taylor \& Francis Group: Boca Raton, FL, USA, 2009; p. 1016, ISBN 978-1-56670-526-4.

46. Langergraber, G.; Prandtstetten, C.; Pressl, A.; Rohrhofer, R.; Haberl, R. Removal efficiency of subsurface vertical flow constructed wetlands for different organic loads. Water Sci. Technol. 2007, 56, 75-84. [CrossRef] [PubMed]

47. Albuquerque, A.; Arendacz, M.; Gajewska, M.; Obarska-Pempkowiak, H.; Randerson, P.; Kowalik, P. Removal of organic matter and nitrogen in a horizontal subsurface flow (HSSF) constructed wetland under transient loads. Water Sci. Technol. 2009, 60, 1677-1682. [CrossRef] [PubMed]

48. Albuquerque, A.; Oliveira, J.; Semitela, S.; Amaral, L. Influence of bed media characteristics on ammonia and nitrate removal in shallow horizontal subsurface flow constructed wetlands. Bioresour. Technol. 2009, 100, 6269-6277. [CrossRef] [PubMed]

49. Megonikal, J.P.; Hines, M.E.; Visscher, P.T. Anaerobic Metabolism: Linkage to Trace Gases and Aerobic Processes. In Biogeochemistry; Schlesinger, W.H., Ed.; Elsevier-Pergamon: Oxford, UK, 2004; pp. 317-424.

50. Mitchell, C.; McNevin, D. Alternative analysis of BOD removal in subsurface flow constructed wetlands employing Monod kinetics. Water Res. 2001, 35, 1295-1303. [CrossRef]

51. Marzec, M.; Gizińska-Górna, M.; Jóźwiakowski, K.; Pytka-Woszczyło, A.; Kowalczyk-Juśko, A.; Gajewska, M. The efficiency and reliability of pollutant removal in a hybrid constructed wetland with giant miscanthus and Jerusalem artichoke in Poland. Ecol. Eng. 2019, 127, 23-35. [CrossRef]

52. Marzec, M.; Jóźwiakowski, K.; Dębska, A.; Gizińska-Górna, M.; Pytka, A.; Kowalczyk-Juśko, A.; Listosz, A. The Efficiency and Reliability of Pollutant Removal in a Hybrid Constructed Wetland with Common Reed, Manna Grass, and Virginia Mallow. Water 2018, 10, 1445. [CrossRef]

53. Jia, W.; Zhang, J.; Wu, J.; Xie, H.; Zhang, B. Effect of intermittent operation on contaminant removal and plant growth in vertical flow constructed wetlands: A microcosm experiment. Desalination 2010, 262, 202-208. [CrossRef] 
54. Gervin, L.; Brix, H. Removal of nutrients from combined sewer overflows and lake water in a vertical-flow constructed wetland system. Water Sci. Technol. 2001, 44, 171-176. [CrossRef]

55. Vera, L.; Martel, G.; Márquez, M. First year performance of a new constructed wetland on the island of Gran Canaria: A case Study. In Proceedings of the 12th International Conference on Wetland Systems for Water Pollution Control, Venice, Italy, 4-8 October 2010; Masi, F., Nivala, J., Eds.; International Water Association: London, UK, 2012; pp. 1037-1044.

56. Melián, J.H.; Rodríguez, A.M.; Araña, J.; Díaz, O.G.; Henríquez, J.G. Hybrid constructed wetlands for wastewater treatment and reuse in the Canary Islands. Ecol. Eng. 2010, 36, 891-899. [CrossRef]

57. Sharma, P.K.; Inoue, T.; Kato, K.; Ietsugu, H.; Tomita, K.; Nagasawa, T. Potential of hybrid constructed wetland system in treating milking parlor wastewater under cold climatic conditions in northern Hokkaido, Japan. Water Pract. Technol. 2011, 6, 1-2. [CrossRef]

58. Ghrabi, A.; Bousselmi, L.; Masi, F.; Regelsberger, M. Constructed wetland as a low cost and sustainable solution for wastewater treatment adapted to rural settlements: The Chorfech wastewater treatment pilot plant. Water Sci. Technol. 2011, 63, 3006-3012. [CrossRef]

59. Shrestha, R.; Haberl, R.; Laber, J.; Manandhar, R.; Mader, J. Application of constructed wetlands for wastewater treatment in Nepal. Water Sci. Technol. 2001, 44, 381-386. [CrossRef] [PubMed]

60. Rivas, A.; Barceló-Quintal, I.; Moeller, G.E. Pollutant removal in a multi-stage municipal wastewater treatment system comprised of constructed wetlands and a maturation pond, in a temperate climate. Water Sci. Technol. 2011, 64, 980-987. [CrossRef] [PubMed]

61. Singh, S.; Haberl, R.; Moog, O.; Shrestha, R.R.; Shrestha, P.; Shrestha, R. Performance of an anaerobic baffled reactor and hybrid constructed wetland treating high-strength wastewater in Nepal e a model for DEWATS. Ecol. Eng. 2009, 35, 654-660. [CrossRef]

62. Ayaz, S.; Aktas, O.; Findik, N.; Akça, L.; Kınacı, C.; Fındık, N.; Kinaci, C. Effect of recirculation on nitrogen removal in a hybrid constructed wetland system. Ecol. Eng. 2012, 40, 1-5. [CrossRef]

63. Laber, J.; Haberl, R.; Langergraber, G. Treatment of Hospital Wastewater with a 2-Stage Constructed Wetland System. In Achievments and Prospects of Phytoremediation in Europe; Haberl, R., Langergraber, G., Eds.; University of Natural Resources and Applied Life Sciences: Vienna, Austria, 2003; p. 85.

64. Seo, D.C.; Delaune, R.D.; Park, W.Y.; Lim, J.S.; Seo, J.Y.; Lee, D.J.; Cho, J.S.; Heo, J.S. Evaluation of a hybrid constructed wetland for treating domestic sewage from individual housing units surrounding agricultural villages in South Korea. J. Environ. Monit. 2009, 11, 134-144. [CrossRef]

65. Wu, S.; Carvalho, P.N.; Müller, J.A.; Manoj, V.R.; Dong, R. Sanitation in constructed wetlands: A review on the removal of human pathogens and fecal indicators. Sci. Total Environ. 2016, 541, 8-22. [CrossRef]

66. Foladori, P.; Ortigara, A.R.C.; Ruaben, J.; Andreottola, G. Influence of high organic loads during the summer period on the performance of hybrid constructed wetlands (VSSF + HSSF) treating domestic wastewater in the Alps region. Water Sci. Technol. 2012, 65, 890-897. [CrossRef]

67. Chang, J.-J.; Wu, S.-Q.; Dai, Y.-R.; Liang, W.; Wu, Z.-B. Nitrogen removal from nitrate-laden wastewater by integrated vertical-flow constructed wetland systems. Ecol. Eng. 2013, 58, 192-201. [CrossRef]

68. Poach, M.; Hunt, P.; Reddy, G.; Stone, K.; Johnson, M.; Grubbs, A. Swine wastewater treatment by marsh-pond-marsh constructed wetlands under varying nitrogen loads. Ecol. Eng. 2004, 23, 165-175. [CrossRef]

69. Pietro, K.C.; Ivanoff, D. Comparison of long-term phosphorus removal performance of two large-scale constructed wetlands in South Florida, U.S.A. Ecol. Eng. 2015, 79, 143-157. [CrossRef]

70. Zapater-Pereyra, M.; Ilyas, H.; Lavrnić, S.; Van Bruggen, J.; Lens, P.N.L. Evaluation of the performance and space requirement by three different hybrid constructed wetlands in a stack arrangement. Ecol. Eng. 2015, 82, 290-300. [CrossRef]

71. Öövel, M.; Tooming, A.; Mauring, T.; Mander, Ü. Schoolhouse wastewater purification in a LWA-filled hybrid constructed wetland in Estonia. Ecol. Eng. 2007, 29, 17-26. [CrossRef]

72. Leto, C.; Tuttolomondo, T.; La Bella, S.; Leone, R.; Licata, M. Effects of plant species in a horizontal subsurface flow constructed wetland-Phytoremediation of treated urban wastewater with Cyperus alternifolius L. and Typha latifolia L. in the West of Sicily (Italy). Ecol. Eng. 2013, 61, 282-291. [CrossRef]

73. Zhao, Y.J.; Hui, Z.; Chao, X.; Nie, E.; Li, H.J.; He, J.; Zheng, Z. Efficiency of two-stage combinations of subsurface vertical down-flow and up-flow constructed wetland systems for treating variation in influent C/N ratios of domestic wastewater. Ecol. Eng. 2011, 37, 1546-1554. [CrossRef] 
74. Bulc, T.G. Long term performance of a constructed wetland for landfill leachate treatment. Ecol. Eng. 2006, 26, 365-374. [CrossRef]

75. Chazarenc, F.; Gérard, M.; Gonthier, Y. Hydrodynamics of horizontal subsurface flow constructed wetlands. Ecol. Eng. 2003, 21, 165-173. [CrossRef]

76. Chazarenc, F.; Naylor, S.; Comeau, Y.; Merlin, G.; Brisson, J. Modeling the Effect of Plants and Peat on Evapotranspiration in Constructed Wetlands. Int. J. Chem. Eng. 2010, 2010, 1-6. [CrossRef]

77. Herbst, M.; Kappen, L. The ratio of transpiration versus evaporation in a reed belt as influenced by weather conditions Author links open overlay panel. Aquatic Bot. 1999, 63, 113-125. [CrossRef]

78. Toscano, A.; Marzo, A.; Milani, M.; Cirelli, G.L.; Barbagallo, S. Comparison of removal efficiencies in Mediterranean pilot constructed wetlands vegetated with different plant species. Ecol. Eng. 2015, 75, 155-160. [CrossRef]

79. Langergraber, G. The role of plant uptake on the removal of organic matter and nutrients in subsurface flow constructed wetlands: A simulation study. Water Sci. Technol. 2005, 51, 213-223. [CrossRef] [PubMed]

80. Wu, H.; Zhang, J.; Li, C.; Fan, J.; Zou, Y. Mass Balance Study on Phosphorus Removal in Constructed Wetland Microcosms Treating Polluted River Water. CLEAN Soil Air Water 2013, 41, 844-850. [CrossRef]

81. Wu, H.; Zhang, J.; Wei, R.; Liang, S.; Li, C.; Xie, H. Nitrogen transformations and balance in constructed wetlands for slightly polluted river water treatment using different macrophytes. Environ. Sci. Pollut. Res. 2012, 20, 443-451. [CrossRef]

82. Ouellet Plamondon, C.; Chazarenc, F.; Comeau, Y.; Brisson, J. Artificial aeration to increase pollutant removal efficiency of constructed wetlands in cold climate. Ecol. Eng. 2006, 27, 258-264. [CrossRef]

83. Andraka, D.; Dzienis, L. Required reliability level of wastewater treatment plants according to European and Polish regulations. Zeszyty Naukowe Politechniki Białostockiej. Ser. Inżynieria Środowiska 2003, 16, 24-28. (In Polish)

84. Wałega, A.; Miernik, W.; Kozień, T. The efficiency of a domestic sewage treatment plant type RetroFAST. Przem. Chem. 2008, 87, 210-212. (In Polish)

85. Marzec, M. Reliability of removal of selected pollutants in different technological solutions of household wastewater treatment plants. J. Water Land Dev. 2017, 35, 141-148. [CrossRef]

Publisher's Note: MDPI stays neutral with regard to jurisdictional claims in published maps and institutional affiliations.

(C) 2020 by the authors. Licensee MDPI, Basel, Switzerland. This article is an open access article distributed under the terms and conditions of the Creative Commons Attribution (CC BY) license (http://creativecommons.org/licenses/by/4.0/). 